\title{
Estimating crop coefficients from fraction of ground cover and height
}

\author{
Richard G. Allen $\cdot$ Luis S. Pereira
}

Received: 13 May 2009/Accepted: 15 July 2009/Published online: 16 September 2009

(C) Springer-Verlag 2009

\begin{abstract}
The FAO-56 procedure for estimating the crop coefficient $K_{\mathrm{c}}$ as a function of fraction of ground cover and crop height has been formalized in this study using a density coefficient $K_{\mathrm{d}}$. The density coefficient is multiplied by a basal $K_{\mathrm{c}}$ representing full cover conditions, $K_{\mathrm{cb} \text { full }}$, to produce a basal crop coefficient that represents actual conditions of ET and vegetation coverage when the soil surface is dry. $K_{\mathrm{cb} \text { full }}$ is estimated primarily as a function of crop height. $K_{\mathrm{cb}}$ full can be adjusted for tree crops by multiplying by a reduction factor $\left(F_{\mathrm{r}}\right)$ estimated using a mean leaf stomatal resistance term. The estimate for basal crop coefficient, $K_{\mathrm{cb}}$, is further modified for tree crops if some type of ground-cover exists understory or between trees. The single (mean) crop coefficient is similarly estimated and is adjusted using a $K_{\text {soil }}$ coefficient that represents background evaporation from wet soil. The $K_{\mathrm{c}}$ estimation procedure was applied to the development periods for seven vegetable crops grown in California. The average root mean square error between estimated and measured $K_{\mathrm{c}}$ was 0.13 . The $K_{\mathrm{c}}$ estimation procedure was also used to estimate $K_{\mathrm{c}}$ during midseason periods of horticultural crops (trees and vines) reported in the literature. Values for mean leaf stomatal resistance and the $F_{\mathrm{r}}$ reduction factor were derived that explain the literature $K_{\mathrm{c}}$ values and that provide a consistent means to estimate $K_{\mathrm{c}}$ over a broad range of fraction of ground cover.
\end{abstract}

Communicated by S. Ortega-Farias.

R. G. Allen ( $\square)$

University of Idaho, Idaho, USA

e-mail: rallen@uidaho.edu

L. S. Pereira

Technical University of Lisbon, Lisbon, Portugal

\section{Introduction}

The two-step crop coefficient $\left(K_{\mathrm{c}}\right) \times$ reference evapotranspiration $\left(\mathrm{ET}_{\mathrm{ref}}\right)$ method has been a successful and dependable means to estimate evapotranspiration (ET) and crop water requirements. The method utilizes weather data to estimate ET for a reference condition and multiplies that estimate by a crop coefficient that represents the relative rate of ET from a specific crop and condition to that of the reference. The reference condition is generally ET from a clipped, cool season, well-watered grass $\left(\mathrm{ET}_{\mathrm{o}}\right)$ or from a taller full-cover alfalfa crop $\left(\mathrm{ET}_{\mathrm{r}}\right)$. The calculation of ET from these surfaces has been standardized by FAO (Allen et al. 1998, 2006) and the American Society of Civil Engineers (ASCE-EWRI 2005).

The $K_{\mathrm{c}} \mathrm{ET}_{\text {ref }}$ approach provides a simple, convenient and reproducible way to estimate ET from a variety of crops and climatic conditions (Doorenbos and Pruitt 1977; Wright 1982; Snyder et al. 1989a, b; Allen et al. 1998). Developed $K_{\mathrm{c}}$ curves or values represent the ratios of $\mathrm{ET}_{\mathrm{c}}$. to $\mathrm{ET}_{\text {ref }}$ during various growth stages. Crop coefficient values have been reported for a wide range of agricultural crops (Allen et al. 1998, 2007a). The $K_{\mathrm{c}}$ is regarded as generally transferable among regions and climates under the assumption that the $\mathrm{ET}_{\text {ref }}$ accounts for nearly all variation caused by weather and climate. Therefore, the $K_{\mathrm{c}}$ represents the relative fraction of $\mathrm{ET}_{\text {ref }}$, and is chiefly governed by the amount, type and condition of vegetation. Vegetation characteristics are more consistent for agricultural vegetation than for natural vegetation. Tabular values for $K_{\mathrm{c}}$ are often successfully used over a wide range of agricultural applications. Transferability of $K_{\mathrm{c}}$ values is supported, in the case of the grass reference ET, by an equation that adjusts tabularized $K_{\mathrm{c}}$ to climate as a function of daily minimum relative humidity, wind speed, and crop height (Allen et al. 1998). 
Conversely, the vegetation amount, height, and density of many systems, including natural vegetation, orchards, and residential and rural landscapes, is highly variable, even during the middle part of the growing season, so that substantial uncertainties exist with tabularized values for these systems. Under these conditions, $K_{\mathrm{c}}$ values can be more accurately estimated by basing the estimates on the fraction of ground covered or shaded by vegetation, the height of the vegetation, and the amount of stomatal regulation under moist soil conditions. The value for $K_{\mathrm{c}}$ for conditions of low soil water availability is generally determined by reducing the $K_{\mathrm{c}}$ estimate via $K_{\mathrm{s}}$ using a daily soil water balance model.

This paper describes a relatively simple approach for estimating the $K_{\mathrm{c}}$ value based on a physical description of the vegetation. The method traces to the FAO-56 publication (Allen et al. 1998) with extensions made to account for background evaporation from soil and better seamlessness of the procedure. The procedure is intended for estimating both basal and average $K_{\mathrm{c}}$ for natural vegetation, orchards and landscape systems for different portions of the growing season based on amount of vegetation present and background evaporation from soil.

\section{Background}

\section{Basal crop coefficient}

Basal crop coefficients, $K_{\mathrm{cb}}$, represent primarily the transpiration component of ET and a small evaporation component from soil that is visibly dry at the surface. The use of $K_{\mathrm{cb}}$ over long periods requires adjustment for evaporation from wet soil during periods following rain or irrigation. The total crop coefficient, $K_{\mathrm{c}}$ is computed from $K_{\mathrm{cb}}$ as:

$K_{\mathrm{c}}=K_{\mathrm{s}} K_{\mathrm{cb}}+K_{\mathrm{e}}$

where $K_{\mathrm{s}}$ is a dimensionless 'stress' coefficient whose value is dependent on available soil water and $K_{\mathrm{e}}$ is a coefficient that adjusts for increased evaporation from wet soil following rain or irrigation. The procedure in Eq. 1 has been referred to as the 'dual' $K_{\mathrm{c}}$ approach (Allen et al. 1998, 2005a). The values for $K_{\mathrm{e}}$ create "spikes" in the $K_{\mathrm{c}}$ curve as shown in Fig. 1. Estimation of $K_{\mathrm{e}}$ for bare soil conditions is described in Wright (1982) and Allen et al. $(1998,2005 \mathrm{a}, \mathrm{b})$. The value for $K_{\mathrm{s}}$ is 1 unless available soil water limits transpiration, in which case it has a value less than 1. Calculation of $K_{\mathrm{s}}$ (and $K_{\mathrm{e}}$ ) requires a daily soil water balance as described in Allen et al. (1998, 2005a, 2007a) and Cholpankulov et al. (2008) and the specification of a shape function for $K_{\mathrm{s}}$ versus soil water content or soil water potential. The value specified for the soil water threshold at which water stress begins does impact the $K_{\mathrm{c}}$

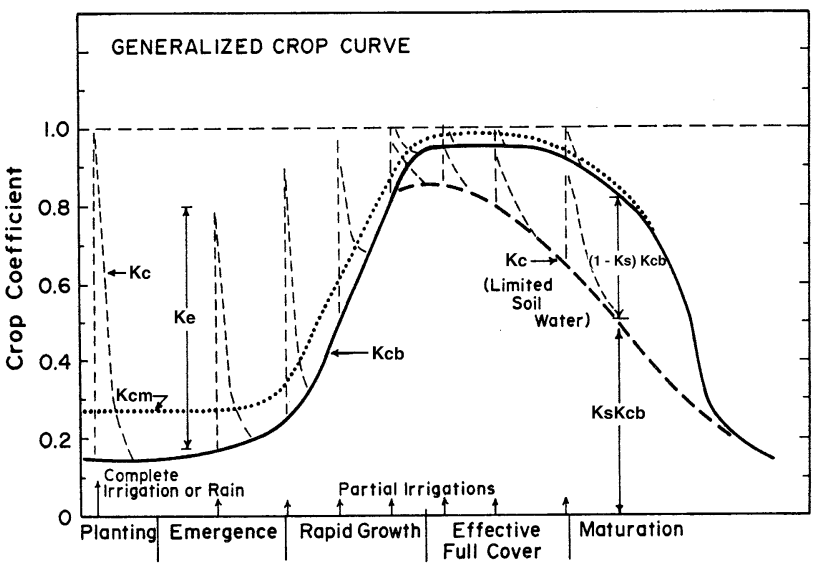

Fig. 1 Generalized crop coefficient curves, $K_{\mathrm{c}}$, for an annual field crop over a growing season showing the effects of increasing $K_{\mathrm{c}}$ during midseason caused by plant development $\left(K_{\mathrm{cb}}\right)$, wet soil surface $\left(K_{\mathrm{e}}\right)$ and (long-dashed curve) limited available soil water $\left(K_{\mathrm{s}} K_{\mathrm{cb}}\right) . K_{\mathrm{cm}}$ is the single $K_{\mathrm{c}}$ representing averaged evaporation effects (after Wright 1982; Jensen et al. 1990)

estimation and may need to be determined locally (Popova et al. 2006; Raes et al. 2009).

Single crop coefficients

In basin-wide water balance studies or irrigation systems planning, use of 'single' crop coefficients that imbed averaged effects of evaporation from wet soil are more useful and convenient than computing a daily $K_{\mathrm{c}}$ based on $K_{\mathrm{cb}}, K_{\mathrm{s}}$, and $K_{\mathrm{e}}$. The single crop curve, $K_{\mathrm{cm}}$, shown in Fig. 1 lies above the basal curve by an amount that depends on the frequency of soil wetting. The $K_{\mathrm{cm}}$ is in essence a 'timeaveraged' $K_{\mathrm{c}}$ as opposed to the 'dual $K_{\mathrm{c}}$ '. When a single crop coefficient is used, usually no additional adjustment is made for the effects of surface soil wetness. Adjustments are made for the effects of limited soil water as:

$K_{\mathrm{c}}=K_{\mathrm{s}} K_{\mathrm{cm}}$

Values for $K_{\mathrm{cm}}$ during partial crop cover depend not only on the amount and type of vegetation cover, but also on frequency of precipitation and irrigation and whether irrigation wets all or part of the soil surface. $K_{\mathrm{cm}}$ curves can be generated from $K_{\mathrm{cb}}$ curves for known or simulated precipitation or irrigation frequencies following the dual $K_{\mathrm{cb}}$ approach and daily timestep.

\section{Segmented crop coefficient curves}

Figure 1 shows realistic $K_{\mathrm{c}}$ curves that have smooth, continuous transitions during the growing season. $K_{\mathrm{c}}$ curves have often been constructed, for simplicity in construction and estimation, using the FAO segmented approach shown in Fig. 2 where the continuous seasonal curve is broken 


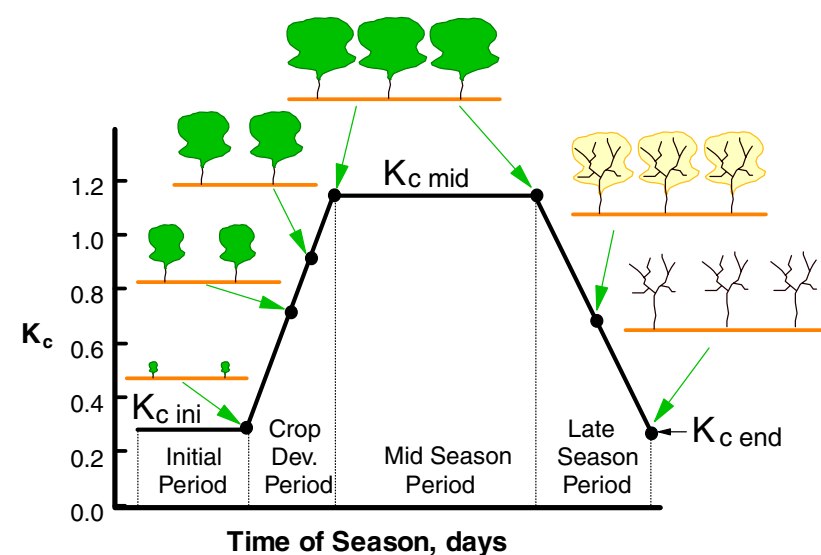

Fig. 2 FAO segmented crop coefficient curve and four growing stages (after Allen et al. 1998)

into four linear segments representing the initial, development, midseason, and late season periods (Doorenbos and Pruitt 1977; Allen et al. 1998, 2005a). The appeal of the FAO style curve is that only three key values for $K_{\mathrm{c}}$ need to be determined: $K_{\mathrm{c}}$ ini during the initial period, $K_{\mathrm{c} \text { mid }}$ during the midseason period, and $K_{\mathrm{c} \text { end }}$ at the end if the late season period. Values for $K_{\mathrm{c} \text { ini }}, K_{\mathrm{c} \text { mid }}$ and $K_{\mathrm{c}}$ end are listed in FAO-56 (Allen et al. 1998, 2007a). The FAO style curve can be applied equally well to basal and single $K_{\mathrm{c}}$ applications in both dual and single mode. Examples of application of the FAO style $K_{\mathrm{cb}}$ curves in a dual $K_{\mathrm{c}}$ model include Hunsaker (1999), Tolk and Howell (2001), de Medeiros et al. (2001), Ringersma and Sikking (2001), Hunsaker et al. (2002, 2003, 2005), Pereira et al. (2003), Howell et al. (2004), Mutziger et al. (2005), Allen et al. (2005a, 2007a), Paço et al. (2006), Spohrer et al. (2006), Rolim et al. (2006), Kato and Kamichika (2006), Goodwin et al. (2006), Zhao and Nan (2007), Bodner et al. (2007), Er-Raki et al. (2007), López-Urrea et al. (2009a, b, c), Greenwood et al. (2009), and Yang et al. (2009).

The procedures for constructing $K_{\mathrm{c}}$ curves presented in the following apply to both grass and alfalfa reference bases. Therefore, distinction is made between those $K_{\mathrm{c}}$ values that apply to grass reference and those that apply to the alfalfa reference by denoting the former as $K_{\mathrm{co}}$ and the latter as $K_{\mathrm{cr}}$. The two types of $K_{\mathrm{c}}$ 's should not be interchanged, because $K_{\text {co }}$ is generally $20-30 \%$ larger than $K_{\mathrm{cr}}$. The larger values for $K_{\mathrm{co}}$ are required because $\mathrm{ET}_{\mathrm{o}}$ tends to be $20-40 \%$ smaller than $\mathrm{ET}_{\mathrm{r}}$.

\section{Adjusting $K_{\text {co }}$ for climate}

The ratio of $\mathrm{ET}_{\mathrm{c} \text {. }}$ to grass $\mathrm{ET}_{\mathrm{o}}$ for many crops increases as wind speed increases and as minimum daily relative humidity decreases (Doorenbos and Pruitt 1977). This is due primarily to differences in roughness between taller agricultural crops and the clipped grass reference. The result is a higher $K_{\text {co }}$ value caused by increased roughness and perhaps leaf area making the aerodynamic aspects of vapor transport more important and significant. The adjustment to $K_{\mathrm{co}}$ is generally required only for coefficients based on the grass $\mathrm{ET}_{\mathrm{o}}$ reference. No adjustment for climate is necessary for coefficients based on the alfalfa $\mathrm{ET}_{\mathrm{r}}$ reference because of the greater roughness of alfalfa that is more similar to most crops (Wright 1982; Pereira et al. 1999). The FAO procedure for adjusting $K_{\text {co }}$ values uses mean daily minimum relative humidity and wind speed. For climates with $\mathrm{RH}_{\min }$ greater than or less than $45 \%$ or with mean wind speeds at $2 \mathrm{~m}$ over grass $\left(u_{2}\right)$ that are more than or less than $2.0 \mathrm{~m} \mathrm{~s}^{-1}$, the standardized values for all $K_{\text {co mid }}$ and $K_{\text {cbo mid }}$ from FAO-56 and for $K_{\text {co end }}$ and $K_{\text {cbo end }}>0.4$ are adjusted as:

$$
\begin{aligned}
K_{\text {co mid } / \text { end }}= & K_{\text {co mid } / \text { end }(\text { table })} \\
& +\left[0.04\left(u_{2}-2\right)-0.004\left(\mathrm{RH}_{\min }-45\right)\right]\left(\frac{h}{3}\right)^{0.3}
\end{aligned}
$$

where $K_{\text {co mid/end(table) }}$ is the value for $K_{\text {co mid }}, K_{\text {cbo mid }}$, $K_{\text {co end }}$ or $K_{\text {cbo end }}$ for the standardized climate and $h$ is the mean maximum plant height $(\mathrm{m})$ during the midseason period, or full cover period. Equation 3 is valid for $h<20 \mathrm{~m}$ (Allen et al. 1998, 2005a). The values for $\mathrm{RH}_{\min }$ and $u_{2}$ need only be approximate values averaged over the midseason and late season periods.

\section{Estimating $K_{\mathrm{c}}$ curves from fraction of ground cover}

Natural vegetation systems tend to have extensive variability in vegetation density, plant height, and water availability, both within a single expanse and between expanses of the same vegetation. Therefore, the distribution of $K_{\mathrm{c}}$ and thus ET populations can be broad, as shown in Fig. 3, where a frequency distribution of ET for the month of June and calendar year for cottonwood and salt cedar populations along a $100-\mathrm{km}$ stretch of the Middle Rio Grande valley is shown as derived from satellite-based energy balance (Allen et al. 2007b). ET from salt cedar showed larger variance due to its tendency to grow across a broad range of water availability (water table depth), soil types, and salinity conditions, whereas cottonwoods, which exhibited a smaller variance in the population of ET, are typically found close to stream channels and consistent water supply. Wide variation was also noted for tree population density, which added to variance in the populations of ET.

For expanses of vegetation large enough that an equilibrium boundary layer is established so that general onedimensional equations such as the Penman-Monteith apply, a maximum upper limit on ET is established due to the law of 
Fig. 3 Frequency distributions of ET from 6,000 ha of cottonwood and salt cedar along the Middle Rio Grande in New Mexico during June and all of 2002
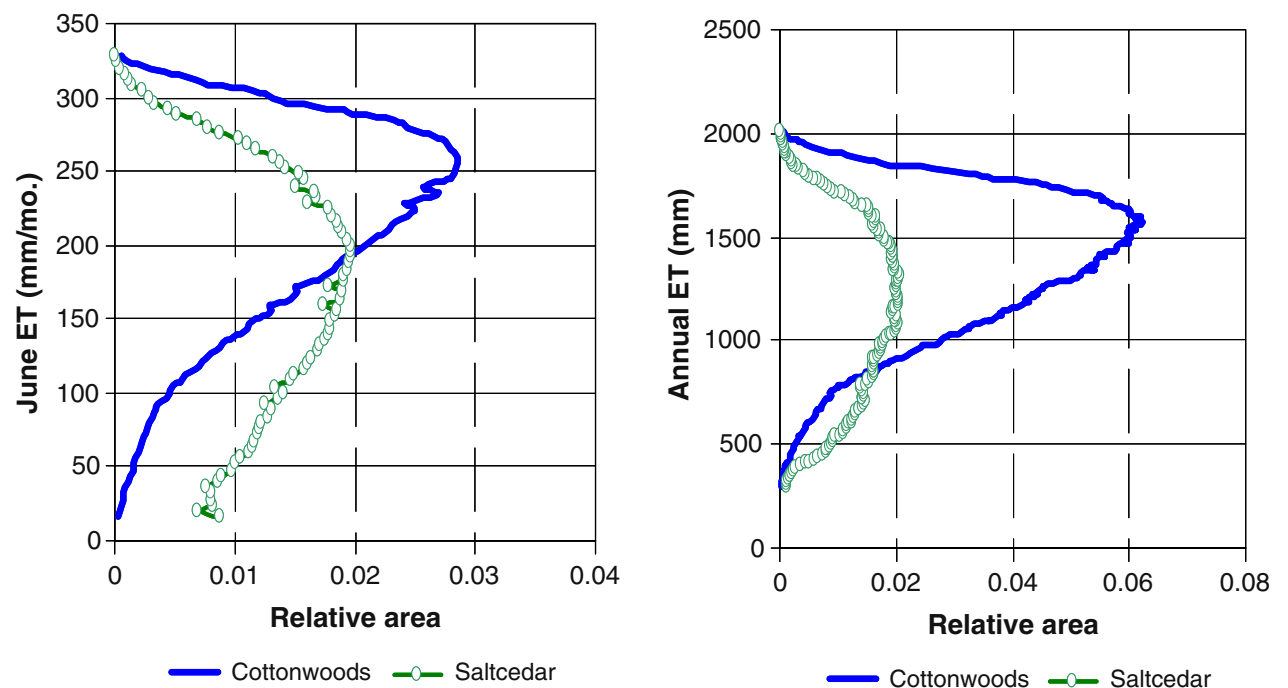

conservation of energy. Therefore, for large expanses of vegetation (larger than about $500-2,000 \mathrm{~m}^{2}$ ), the $K_{\mathrm{c}}$ development process has upper limits for $K_{\text {cr }}$ of about 1.1 for the alfalfa reference and upper limits for $K_{\mathrm{co}}$ of about 1.3 for the grass reference. $K_{\mathrm{c}}$ 's for smaller expanses $\left(<500 \mathrm{~m}^{2}\right)$ should also adhere to these limits when the vegetation height and leaf area is less than or equal to that of surrounding vegetation and soil water availability is similar. Only under conditions of "clothesline effects" (where vegetation height exceeds that of the surroundings) or "oasis effects" (where vegetation has higher soil water availability than the surroundings) will peak $K_{\mathrm{c}}$ 's exceed the limits stated. The user should exercise caution when extrapolating ET measurements from small vegetation stands or plots to large stands or regions, as overestimation of ET may occur.

The upper, energy-constrained limit on $K_{\mathrm{c}}$ can be used to advantage in estimating $K_{\mathrm{c}}$ for vegetation for which the $K_{\mathrm{c}}$ is unknown, by using it to set the upper limit for vegetation having full or nearly full ground cover. This upper limit, termed $K_{\mathrm{c} \text { max }}$ is defined as the maximum value for $K_{\mathrm{c}}$ following rain or irrigation. The value for $K_{\mathrm{c} \max }$ is governed by the amount of energy available for evaporation of water, which is largely encapsulated in $\mathrm{ET}_{\text {ref. }}$ As with the case of $K_{\mathrm{co}}$, the $K_{\mathrm{c} \text { max }}$ used with $\mathrm{ET}_{\mathrm{o}}$ varies with general climate, ranging from about 1.05 to 1.30 (Allen et al. 1998, 2005a):

$$
\begin{aligned}
K_{\mathrm{c} \max \mathrm{o}}= & \max \left(\left\{1.2+\left[0.04\left(u_{2}-2\right)\right.\right.\right. \\
& \left.\left.\left.-0.004\left(R H_{\min }-45\right)\right]\left(\frac{h}{3}\right)^{0.3}\right\},\left\{K_{\mathrm{cbo}}+0.05\right\}\right)
\end{aligned}
$$

where $u_{2}$ is average wind speed at $2 \mathrm{~m}$ during the particular growth stage or period, $\mathrm{RH}_{\min }$ is average daily minimum relative humidity during the growth state or period and $h$ is the mean plant height $(\mathrm{m})$ during the period of calculation (initial, development, midseason, or late-season). The $K_{\text {cbo }}$ denotes a basal $K_{\mathrm{cb}}$ used with $\mathrm{ET}_{\mathrm{o}}$ estimated in a later section.

$K_{\mathrm{c} \max }$ for the tall reference $\mathrm{ET}_{\mathrm{r}}$, denoted as $K_{\mathrm{c} \max }$, does not require adjustment for climate, due to the greater roughness of the alfalfa reference basis:

$K_{\mathrm{c} \max \mathrm{r}}=\max \left(1.0,\left\{K_{\mathrm{cbr}}+0.05\right\}\right)$

where $K_{\mathrm{cbr}}$ denotes a basal $K_{\mathrm{cb}}$ used with $\mathrm{ET}_{\mathrm{r}}$. Equations $4 \mathrm{a}$ and $4 \mathrm{~b}$ require that $K_{\mathrm{c} \text { max }}$ is greater than or equal to the sum $K_{\mathrm{cb}}+0.05$, suggesting that wet soil increases the $K_{\mathrm{c}}$ value above $K_{\mathrm{cb}}$ by at least 0.05 following complete wetting of the soil surface, even during periods of full ground cover.

The value for $K_{\mathrm{c}}$ reduces when plant density or leaf area fall below full ground cover which, in some cases, has been defined as when leaf area index LAI $<3$. Because the $K_{\mathrm{c}}$ tends to decrease in proportion to the amount of vegetation, the basal $K_{\mathrm{cb}}$, which correlates with amount of vegetation because it represents mostly transpiration, can be expressed in terms of a density coefficient, $K_{\mathrm{d}}$, where:

$K_{\mathrm{cb}}=K_{\mathrm{c} \min }+K_{\mathrm{d}}\left(K_{\mathrm{cb} \text { full }}-K_{\mathrm{c} \min }\right)$

where $K_{\mathrm{cb}}$ is the approximation for $K_{\mathrm{cb}}$ for conditions represented by the density coefficient, $K_{\mathrm{d}}, K_{\mathrm{cb}}$ full is the estimated basal $K_{\mathrm{c}}$ during peak plant growth for conditions having nearly full ground cover (or LAI $>3$ ), and $K_{\mathrm{c} \min }$ is the minimum basal $K_{\mathrm{c}}$ for bare soil $\left(K_{\mathrm{cb} \text { min }} \sim 0.15\right.$ under typical agricultural conditions and $K_{\mathrm{cb}} \min 0.0-0.15$ for native vegetation, depending on rainfall frequency). The density coefficient $K_{\mathrm{d}}$ can be estimated as a function of measured or estimated leaf area index LAI or as a function of fraction of ground covered by vegetation. The density coefficient is defined in Eq. 9. 
For tree crops having grass or other ground cover, Eq. 5a can take the form:

$$
\begin{aligned}
K_{\mathrm{cb}}= & K_{\mathrm{cb} \text { cover }} \\
& +K_{\mathrm{d}}\left(\max \left[K_{\mathrm{cb} \text { full }}-K_{\mathrm{cb} \text { cover }}, \frac{K_{\mathrm{cb} \text { full }}-K_{\mathrm{cb} \text { cover }}}{2}\right]\right)
\end{aligned}
$$

where $K_{\mathrm{cb} \text { cover }}$ is the $K_{\mathrm{cb}}$ of the ground cover in the absence of tree foliage. The second term of the max function reduces the estimate for $K_{\mathrm{cb}}$ mid by half the difference between $K_{\mathrm{cb} \text { full }}$ and $K_{\mathrm{cb} \text { cover }}$ when this difference is negative. This accounts for impacts of the shading of the surface cover by overstory vegetation having $K_{\mathrm{cb}}$ that is lower than that of the surface cover due to differences in stomatal conductance. Equations $5 \mathrm{a}$ and $5 \mathrm{~b}$ can be applied to estimate $K_{\mathrm{cb}}$ during any period, including the midseason period. The value for $K_{\text {cb }}$ from Eq. 5a and 5b should be applied as a basal coefficient using the dual $K_{\mathrm{cb}}+K_{\mathrm{e}}$ method, since the actual $K_{\mathrm{c}}$ may increase to 1.0 for $\mathrm{ET}_{\mathrm{r}}$ or 1.2 for $\mathrm{ET}_{\mathrm{o}}$ following precipitation even if the estimated $K_{\mathrm{cb}}$ is small, due to surface evaporation from among sparse vegetation. In addition, $K_{\mathrm{c}}$ should be reduced via $K_{\mathrm{s}}$ when soil water is low.

The value for $K_{\mathrm{cb} \text { cover }}$ in Eq. $5 \mathrm{~b}$ should represent the $K_{\mathrm{cb}}$ of the surface cover in the absence of the overstory cover, because Eq. $5 \mathrm{~b}$ in essence estimates the change in $K_{\mathrm{cb}}$ occurring when an overstory tree or other crop replaces, via shading, some $f_{\mathrm{c}}$ fraction of the surface cover. The value for $K_{\mathrm{cb}}$ cover should reflect the density and vigor of the surface cover as occurring in sunlit areas.

The approach of Eq. 5a and 5b can be similarly applied to estimate a single $K_{\mathrm{cm}}$ coefficient for any period having less than full vegetative cover by accounting for the effect of evaporation from predominately exposed areas of soil among the vegetation, much the same as is done in the dual $K_{\mathrm{cb}}+K_{\mathrm{e}}$ approach:

$K_{\mathrm{cm}}=K_{\text {soil }}+K_{\mathrm{d}}\left(\max \left[K_{\mathrm{c} \text { full }}-K_{\text {soil }}, \frac{K_{\mathrm{c} \text { full }}-K_{\text {soil }}}{2}\right]\right)$

where $K_{\text {soil }}$ represents the average $K_{\mathrm{c}}$ from the non-vegetated (exposed) portion of the surface and reflects the impact of wetting frequency, soil type and relative ET rate (i.e., $\mathrm{ET}_{\mathrm{o}}$ ) during the same period as $K_{\mathrm{d}}$ and $K_{\mathrm{c} \text { full }}$. The $K_{\mathrm{cm}}$ represents an average $K_{\mathrm{c}}$ value that considers the mean impact of evaporation from soil, as does $K_{\mathrm{c}}$ full, representing $K_{\mathrm{c}}$ from a fully covered soil with some background evaporation. $K_{\mathrm{cm}}$ can be used to represent the midseason or other period as defined by $K_{\mathrm{d}}, K_{\mathrm{cm}}$, and $K_{\mathrm{c} \text { full }}$.

For large stand size (greater than about $500 \mathrm{~m}^{2}$ ), $K_{\mathrm{cb}}$ full for use with $\mathrm{ET}_{\mathrm{o}}$ can be approximated as a function of mean plant height and adjusted for climate following Allen et al. (1998):

$$
\begin{aligned}
& \left(\text { for } \mathrm{ET}_{\mathrm{o}}\right) \ldots K_{\mathrm{cb} \text { full }} \\
& =F_{\mathrm{r}}\left(\min (1.0+0.1 h, 1.20)+\left[0.04\left(u_{2}-2\right)\right.\right. \\
& \left.\left.\quad-0.004\left(\mathrm{RH}_{\min }-45\right)\right]\left(\frac{h}{3}\right)^{0.3}\right)
\end{aligned}
$$

For use with alfalfa reference $\mathrm{ET}_{\mathrm{r}}, K_{\mathrm{cb} \text { full }}$ can be estimated as:

$\left(\right.$ for $\left.\mathrm{ET}_{\mathrm{r}}\right) \ldots K_{\mathrm{cb} \text { full }}=F_{r}(\min (0.8+0.1 h, 1.0))$

where $h$ is mean maximum plant height in $\mathrm{m}, u_{2}$ is the mean value for wind speed at $2 \mathrm{~m}$ height during the midseason in $\mathrm{m} \mathrm{s}^{-1}, \mathrm{RH}_{\min }$ is the mean value for minimum daily relative humidity during the mid-season in $\%$, and $F_{\mathrm{r}}$ [0-1] is an adjustment factor relative to crop stomatal control, described below. The climatic correction is not required for $K_{\mathrm{cb}}$ full when used to derive the $K_{\mathrm{cb}}$ for $\mathrm{ET}_{\mathrm{r}}$ because of the aerodynamic and canopy characteristics of the alfalfa reference crop. $K_{\mathrm{c}}$ full can generally be estimated as equivalent to $K_{\mathrm{cb} \text { full }}$ or equal to $K_{\mathrm{cb} \text { full }}+0.05$ following Wright (1982) and Allen et al. (1998).

Equation $7 \mathrm{a}$ suggests that an upper bound for $K_{\mathrm{cb}}$ full is 1.20 for the grass reference basis, prior to adjustment for climate. The value for $K_{\mathrm{c}}$ full represents a general upper limit on $K_{\mathrm{cb} \text { mid }}$ for tall vegetation having full ground cover and LAI $>3$ under full water supply. Equations $7 \mathrm{a}$ and $7 \mathrm{~b}$ produce general approximations for the increase in $K_{\mathrm{cb}}$ full with plant height and climate.

Parameter $F_{\mathrm{r}}$ applies a downward adjustment $\left(F_{\mathrm{r}} \leq 1.0\right)$ if the vegetation exhibits more stomatal control on transpiration than is typical of most annual agricultural crops. $F_{\mathrm{r}}$ may be $<1$ for some types of trees and natural vegetation. Allen et al. (1998) suggested the following calculation for reducer $F_{\mathrm{r}}$ for full cover vegetation, based on the FAO Penman-Monteith equation and assuming full cover conditions:

$\mathrm{F}_{\mathrm{r}} \approx \frac{\Delta+\gamma\left(1+0.34 u_{2}\right)}{\Delta+\gamma\left(1+0.34 u_{2} \frac{r_{1}}{100}\right)}$

where $r_{1}$ is mean leaf resistance for the vegetation in question $\left[\mathrm{s} \mathrm{m}^{-1}\right], \Delta$ is the slope of the saturation vapor pressure versus air temperature curve $\left(\mathrm{kPa} \mathrm{C}^{-1}\right)$, and $\gamma$ is the psychrometric constant $\left(\mathrm{kPa} \mathrm{C}^{-1}\right)$. Factor $F_{\mathrm{r}}$ is multiplied against the estimate for $K_{\mathrm{cb} \text { full }}$ in Eq. 7a to reduce its value. The standard value for $F_{\mathrm{r}}$ is 1.0 because, for most annual agricultural crops, $r_{1}$ is often approximately $100 \mathrm{~s} \mathrm{~m}^{-1}$ (Körner et al. 1979; Allen et al. 1996). Values for $r_{1}$ for many agricultural and non-agricultural plants can be found in those publications and elsewhere, or $r_{1}$ can be estimated by inverting Eq. 8 after solving for $F_{\mathrm{r}}$ by inverting Eq. 7 a or $7 \mathrm{~b}$ using known $K_{\mathrm{cb} \text { full }}$. The application of Eq. 8 and value assigned to $r_{1}$ refers to full cover 
conditions for both the reference $\left(100 \mathrm{~s} \mathrm{~m}^{-1}\right)$ and vegetation in question. Full cover conditions can generally be assumed to occur when the leaf area index (LAI) exceeds about 3 . Where plant leaves and canopy are sparse so that LAI is less than about 3 , even at full cover, the ratio $r_{1} / 100$ in Eq. 8 can be replaced by $r_{\mathrm{s}} / 50$ (or $r_{\mathrm{s}} / 30$ ) where $r_{\mathrm{s}}$ is the estimated bulk canopy resistance for the full cover condition and 50 (or 30) is the value for $r_{\mathrm{s}}$ for the grass reference $\mathrm{ET}_{\mathrm{o}}$ (or alfalfa reference $\mathrm{ET}_{\mathrm{r}}$ ) when applied hourly (Allen et al. 2006). It should be recognized that $r_{1}$ solved by inverting Eq. 7 a and 8 is only an approximate estimate for $r_{1}$ and contains artifacts of the $K_{\mathrm{cb}}$ full measurement, weather data error, and the constructs of the two equations. Therefore, values for $r_{1}$ determined by the inversion are only useful for reuse in Eq. 8.

\section{Density coefficient}

The density coefficient describes the increase in $K_{\mathrm{c}}$ with increase in amount of vegetation. The shape of the $K_{\mathrm{d}}$ curve is curvilinear with LAI or fraction of ground cover because of effects of microadvection of convective and radiative energy from exposed soil and height of vegetation. Where LAI can be measured or approximated, $K_{\mathrm{d}}$ can be approximated under normal conditions using an exponential function by Allen et al. (1998) used for estimating $K_{\mathrm{cb}}$ during midseason (Eq. 97 in FAO 56). The result is:

$K_{\mathrm{d}}=\left(1-\mathrm{e}^{[-0.7 \mathrm{LAI}]}\right)$

where LAI is defined as the area of leaves per area of ground surface averaged over a large area with units of $\mathrm{m}^{2} \mathrm{~m}^{-2}$. Only one side of 'green,' healthy leaves that are active in vapor transfer is counted. The relationship in Eq. 9 is similar to one used by Ritchie (1974).

While estimates of the fraction of ground surface covered by vegetation, $f_{\mathrm{c}}$, are available, the $K_{\mathrm{d}}$ is estimated similar to Allen et al. (1998) as:

$K_{\mathrm{d}}=\min \left(1, M_{L} f_{\mathrm{c} \mathrm{eff}}, f_{\mathrm{c} \text { eff }}^{\left(\frac{1}{1+h}\right)}\right)$ where $f_{\mathrm{c}}$ eff is the effective fraction of ground covered or shaded by vegetation [0.01-1] near solar noon, $M_{L}$ is a multiplier on $f_{\mathrm{c} \text { eff }}$ describing the effect of canopy density on shading and on maximum relative ET per fraction of ground shaded [1.5-2.0], and $h$ is the mean height of the vegetation in $\mathrm{m}$. Estimation of $f_{\mathrm{c}}$ eff was described in Allen et al. (1998). For canopies such as trees or randomly (nonrow) planted vegetation, $f_{\mathrm{c} \text { eff }}$ can be estimated as:

$f_{\mathrm{c} \mathrm{eff}}=\frac{f_{\mathrm{c}}}{\sin (\beta)} \leq 1$

where $\beta$ is the mean angle of the sun above the horizon during the period of maximum ET (generally between 11.00 and 15.00) and $f_{\mathrm{c}}$ is the fraction of surface covered by vegetation as observed from directly overhead. $f_{\mathrm{c}}$ is often determined from visual inspection. However, digital image analysis or other measurement means can be employed. Generally, $f_{\mathrm{c} \text { eff }}$ can be calculated at solar noon (12.00), so that $\beta$ can be calculated as:

$\beta=\arcsin [\sin (\varphi) \sin (\delta)+\cos (\varphi) \cos (\delta)]$

where parameters $\varphi$ and $\Delta$ are latitude $(-\pi / 2 \leq \varphi \leq \pi / 2)$ and solar declination in radians. Allen et al. (1998) provided equations for estimating $\beta$ for row crops as a function of row orientation. A schematic showing $f_{\mathrm{c}}, f_{\mathrm{c}}$ eff and $\beta$ is shown in Fig. 4.

The $M_{L}$ multiplier on $f_{\mathrm{c}}$ eff in Eq. 10 imposes an upper limit on the relative magnitude of transpiration per unit of ground area as represented by $f_{\mathrm{c}}$ eff (Allen et al. 1998) and is expected to range from 1.5 to 2.0 , depending on the canopy density and thickness. Parameter $M_{L}$ is an attempt to simulate the physical limits imposed on water flux through the plant root, stem and leaf systems. The value for $M_{L}$ can be modified to fit the specific vegetation.

Figure 5 shows values for $K_{\mathrm{d}}$ over a range of $f_{\mathrm{c}}$ eff and a range of $h$ for $M_{L}=1.5$ and for $M_{L}=2$ when $h=5 \mathrm{~m}$, showing the effect of $h$ and $M_{L}$ on the estimate. Only $K_{\mathrm{d}}$ for $h$ greater than about $1 \mathrm{~m}$ is impacted by varying the value for $M_{L}$ from 1.5 to 2.0. The estimates by Eq. 10 closely reproduce individual functions previously suggested by
Fig. 4 Schematic showing extent of $f_{\mathrm{c}}, f_{\mathrm{c} \text { eff }}$ and $\beta$ for tree vegetation where $f_{\mathrm{c}}$ is the fraction of surface covered by vegetation as measured from directly overhead

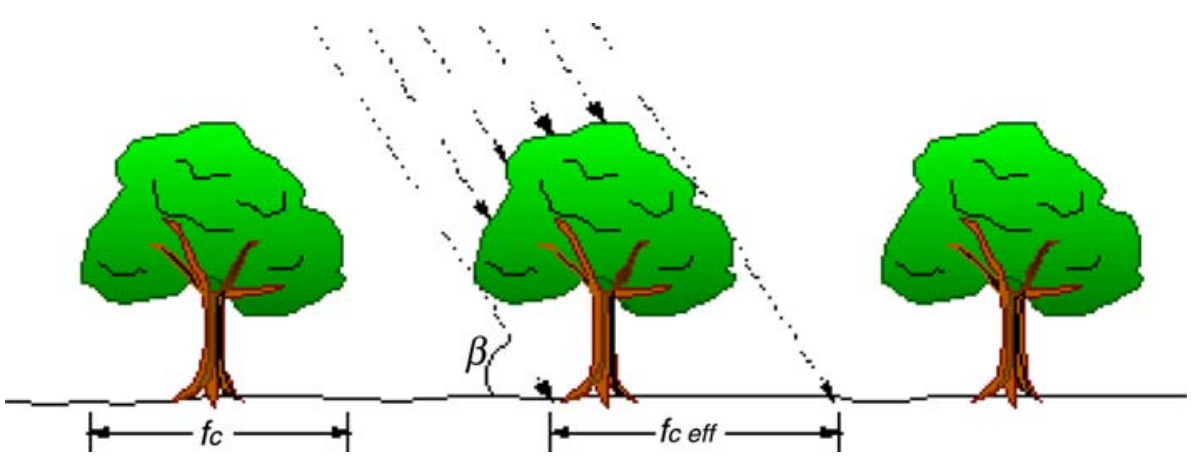




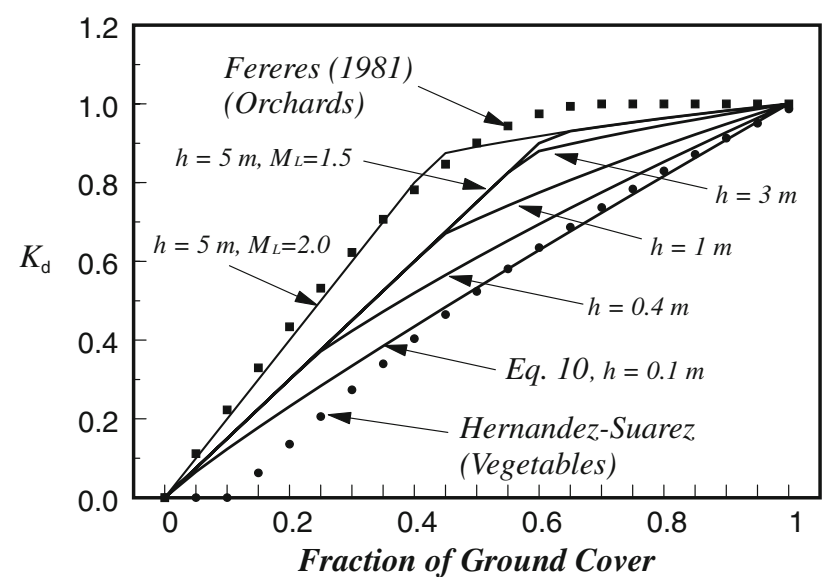

Fig. 5 Density coefficient, $K_{\mathrm{d}}$, estimated from Eq. 10 with $M_{L}=1.5$ over a range of fraction of ground cover and various plant heights, and compared with estimates by Fereres (1981) for orchards and Hernandez-Suarez (1988) for vegetables

Fereres (1981) for orchards (using $M_{L}=2.0$ ) and Hernandez-Suarez (1988) for vegetables. The function by Fereres (1981) is the same as one recommended by Snyder and Eching (2005).

Equation 10 suggests that as $h$ increases, total leaf area and resulting net radiation capture will increase, thereby increasing $K_{\mathrm{c}}$. In addition, as $h$ increases, more opportunity for microadvection and radiation of heat from soil to canopy occurs and turbulent exchange within the canopy increases for the same amount of ground coverage. Both of these increases increase the relative magnitude of $K_{\mathrm{cb}}$ or $K_{\mathrm{c}}$. Values for $K_{\mathrm{cb}}$ or $K_{\mathrm{c}}$ can be scaled from estimates by Eq. 6 or $7 \mathrm{a}$ in proportion to the health and leaf condition of the vegetation at termination and the length of the late season period (i.e., whether leaves senesce slowly or are killed by frost). The $f_{\mathrm{c}}$ parameter and $h$ are probably the simplest indices to estimate in the field.

\section{Comparison of $K_{\mathrm{c}}$ from Eq. 6 based on $K_{\mathrm{d}}$ from Eq. 10 with reported data for vegetables}

The close agreement with Fereres (1981), Snyder and Eching (2005), and Hernandez-Suarez (1988) suggests that the general form of Eq. 10 may be appropriate for a range of vegetation types and heights. The estimation of $K_{\mathrm{c}}$ from Eq. 6 using $K_{\mathrm{c}}$ full from Eq. $7 \mathrm{a}$ and $K_{\mathrm{d}}$ from Eq. 10 was further compared with $K_{\mathrm{c}}$ data and regression equations reported by Grattan et al. (1998) and Hanson and May (2006). Grattan et al. (1998) reported the progression of $K_{\mathrm{c}}$ during plant development for seven vegetable crops in California as measured using Bowen ratio systems. They expressed $K_{\mathrm{c}}$ as a function of percent of ground cover, which is equivalent to $f_{\mathrm{c}}$ so that their data can be compared directly to that from Eqs. 6 and 10. Hanson and May (2006) additionally reported a polynomial equation for $K_{\mathrm{c}}$ versus $f_{\mathrm{c}}$ for tomatoes in California.

Equation 6 for $K_{\mathrm{c}}$ was applied rather than Eq. $5 \mathrm{a}$ for $K_{\mathrm{cb}}$ since some background soil evaporation appeared to be present for some of the crops. $K_{\mathrm{c}}$ full was estimated as equivalent to $K_{\mathrm{cb} \text { full. }}$. In addition, $f_{\mathrm{c}}$ was used in Eq. 10 rather than $f_{\mathrm{c} \text { eff }}$ because specific dates of vegetation development were not reported. Because the sun angle during late spring is high, differences between $f_{\mathrm{c}}$ and $f_{\mathrm{c}}$ eff will be small. Because the crops of Grattan et al. (1998) were all annual or perennial vegetable crops, $F_{\mathrm{r}}$ in Eq. $7 \mathrm{a}$ was set to 1.0 , implying an $r_{1}=100 \mathrm{~s} \mathrm{~m}^{-1}$. The parameters used in Eqs. 6, $7 \mathrm{a}$, and 10 for the vegetable crops are summarized in Table 1 as are root mean square error (RMSE) for the Eq. 6/10 combination and for the original regression equations of Grattan et al. (1998). Comparisons of Eq. 6/10, the regression equations by Grattan et al. and the Grattan et al. data are shown in Fig. 6 for the seven crops. Vegetation height was varied over time in Eq. 10 in proportion to the maximum estimated height times the ratio of specific $f_{\mathrm{c}}$ to $f_{\mathrm{c}}$ at full cover reported by Grattan et al. (1998), with the exception of cantaloupe, which was assumed to have nearly constant height due to its vine nature. Maximum values for $h$ were taken from tables in Allen et al. (1998). A standard climate (wind speed $=2 \mathrm{~m} \mathrm{~s}^{-1}$ and daily minimum relative humidity $=45 \%$ ) was assumed due to lack of reported data by Grattan et al. (1998). Due to the relatively short height of the crops, the adjustment for climate in Eq. 7a would be small.

The agreement between $K_{\mathrm{c}}$ from Eqs. 6, 7a, and 10 and the data of Grattan et al. (1998) was nearly as good as the fitted regression equations reported by Grattan et al. (1998), with the exception of artichokes where the Grattan regression fit the data better with its stronger curve (Fig. 6a). The accuracy of $K_{\mathrm{c}}$ from Eq. 6, 7a, and 10 appears to be within the measurement error of the reported $K_{\mathrm{c}}$ data. When $K_{\text {soil }}=0.15$, Eq. 6 reverts to Eq. 5 a that was developed for the basal $K_{\mathrm{cb}}$. The larger values required for $K_{\text {soil }}$ in Eq. 6 for beans and onion suggest that the soil surface was relatively moist for these two crops, as evidenced by values for measured $K_{\mathrm{c}}$ at low $f_{\mathrm{c}}$. The publication of Hanson and May (2006) (tomato in Fig. 6) did not report the measurement data so that only their regression equation was compared against the product of Eqs. 6, 7a, and 10 . The two estimates compared closely, suggesting that Eqs. 6, 7a, and 10, using readily estimated physical parameters, can be used to estimate $K_{\mathrm{c}}$ if visually assessed or other estimates of $f_{\mathrm{c}}$ are available.

The $K_{\mathrm{c}}$ from Eqs. 6, 7a, and 10 tends to have less curvature versus $f_{\mathrm{c}}$ compared to the curvilinear regression equations of Grattan et al. (1998). The $K_{\mathrm{c}}$ from Eq. 6, 7a, and 10 did express more curvilinearity for the tomato crop 
Table 1 Parameters used in Eqs. 6, 7a, and 10 to estimate $K_{\mathrm{c}}$ for vegetable crops reported by Grattan et al. (1998)

\begin{tabular}{|c|c|c|c|c|c|c|c|c|}
\hline Crop & Artichoke & Beans & Brocolli & Lettuce & Cantaloupe/honeydew & Onion & Strawberry & Tomato \\
\hline$K_{\text {soil }}$ & 0.15 & 0.50 & 0.15 & 0.15 & 0.15 & 0.40 & 0.05 & 0.15 \\
\hline$M_{L}$ & 2.0 & 2.0 & 2.0 & 2.0 & 2.0 & 2.0 & 2.0 & 2.0 \\
\hline$F_{\mathrm{r}}$ & 1.0 & 1.0 & 1.0 & 1.0 & 1.0 & 1.0 & 1.0 & 1.0 \\
\hline $\operatorname{Max} h(\mathrm{~m})$ & 0.6 & 0.4 & 0.3 & 0.3 & 0.3 & 0.4 & 0.2 & 1.2 \\
\hline$h$ versus time & In prop. to $f_{\mathrm{c}}$ & In prop. to $f_{\mathrm{c}}$ & In prop. to $f_{\mathrm{c}}$ & In prop. to $f_{\mathrm{c}}$ & Constant & In prop. to $f_{\mathrm{c}}$ & In prop. to $f_{\mathrm{c}}$ & In prop. to $f_{\mathrm{c}}$ \\
\hline$u_{2}\left(\mathrm{~m} \mathrm{~s}^{-1}\right)$ & 2 & 2 & 2 & 2 & 2 & 2 & 2 & 2 \\
\hline $\mathrm{RH}_{\min }(\%)$ & 45 & 45 & 45 & 45 & 45 & 45 & 45 & 45 \\
\hline No. obs. & 11 & 27 & 34 & 39 & 35 & 14 & 10 & - \\
\hline RMSE $_{\text {Grattan }}$ & 0.09 & 0.09 & 0.13 & 0.16 & 0.09 & 0.10 & 0.05 & - \\
\hline RMSEE$_{\text {Eq. } 6 / 10}$ & 0.15 & 0.10 & 0.14 & 0.17 & 0.10 & 0.11 & 0.10 & - \\
\hline
\end{tabular}

of Hanson and May (2006) (Fig. 6h) due to the taller height of tomatoes compared to the other crops. The $K_{\mathrm{c}}$ from Eq. 6, 7a, and 10 approaches the $K_{\mathrm{cb}}$ full estimated from Eq. 7a as $f_{\mathrm{c}}$ approaches 1.0.

\section{Applications of Eqs. 5a-10 for $K_{c}$ for orchards and grapes}

Equations 5a-10 can be applied to estimate values for $K_{\mathrm{cb}}$ and $K_{\mathrm{c}}$ for various orchard crops and vines, including values representing $K_{\mathrm{cb}}$ and $K_{\mathrm{c}}$ at the beginning, mid- and end of a growing season, namely the $K_{\mathrm{cb} \text { ini, }} K_{\mathrm{cb} \text { mid, }}$, and $K_{\text {cb end }}$ and $K_{\mathrm{c} \text { ini }}, K_{\mathrm{c} \text { mid }}$ and $K_{\mathrm{c} \text { end }}$ as used in the FAO-style linear $K_{\mathrm{c}}$ method of Doorenbos and Pruitt (1977) and Allen et al. (1998). Table 2 lists parameters used in Equations $5 \mathrm{a}-10$ to produce $K_{\mathrm{cb}}$ ini, $K_{\mathrm{cb} \text { mid }}$, and $K_{\mathrm{cb}}$ end and $K_{\mathrm{c} \text { ini }}, K_{\mathrm{c} \text { mid }}$, and $K_{\mathrm{c} \text { end }}$ values for orchard crops as updated by Allen et al. $(2007 \mathrm{a}, 2009)$ and listed in Table 3 , where multiple entries are listed for a range of fraction of cover, $f_{\mathrm{c}}$, summarized from the literature.

A single value is given in Table 2 for $r_{1}$ for each orchard type to represent both beginning and midseason periods. These are the $r_{1}$ values that explain, via Eqs. 7a and 8, the values for $F_{\mathrm{r}}$ that in turn explain, via $K_{\mathrm{cb}}$ full and Eq. 5a or

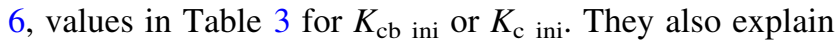
values in Table 3 for $K_{\mathrm{cb} \text { mid }}$ or $K_{\mathrm{c} \text { mid }}$, depending on the Table 3 entry for $f_{\mathrm{c}}$. In Table 3 , ranges of values for $f_{\mathrm{c}}$ and corresponding values for $K_{\mathrm{c}}$ are given, based on reported literature, as footnoted, and as compared to later in Fig. 7. As noted in the next section, the $K_{\mathrm{cb}}$ values from cited measurements represented essentially bare surface conditions so that $F_{\mathrm{r}}$ was calculated by inverting Eq. 5a. The value for $r_{1}$ at the end of the season explains the $F_{\mathrm{r}}$ value required to reduce the $K_{\mathrm{cb}}$ full value estimated from Eqs. 7a and $7 \mathrm{~b}$ to produce values for $K_{\mathrm{cb}}$ end and $K_{\mathrm{c}}$ end that agree with literature values, including those from FAO-56. Nearly all values for $r_{1}$ exceed the $r_{1}=100 \mathrm{~s} \mathrm{~m}^{-1}$ associated with annual agricultural vegetation, indicating various degrees of stomatal control exhibited by orchard and vine crops under typical growing conditions. Olives, mango, citrus and palm had the highest values for $r_{1}$ and therefore lowest values for $F_{\mathrm{r}}$. Olives required $F_{\mathrm{r}}$ of only 0.55 to explain the measured $K_{\mathrm{c}}$ reported primarily from Spain, suggesting substantial stomatal control. Inversion of Eq. 8 to derive the equivalent $r_{1}$ given $F_{\mathrm{r}}$ for olives suggested an $r_{1}$ of about $1,000 \mathrm{~s} / \mathrm{m}$ at $30^{\circ} \mathrm{C}$ air temperature and $700 \mathrm{~s} / \mathrm{m}$ at $20^{\circ} \mathrm{C}$ at sea level. As noted following Eq. 8, it is recognized that $r_{1}$ solved by inverting Eqs. 7a and 8 is only an approximate estimate for $r_{l}$ and contains artifacts of the $K_{\mathrm{cb}}$ full measurement, weather data error, and the constructs of the two equations. Therefore, values for $r_{1}$ determined by the inversion are only useful for assessing relative differences among types of orchard crops and for reuse in Eq. 8. Therefore, $r_{1}$ computed in this way must be evaluated with caution, and further improvements in the calculation procedures as well as input from other researchers is desired.

To utilize Table 2 to estimate $\mathrm{K}_{\mathrm{cb}}$ for initial and late season periods for orchards or vine crops, the user enters the tabulated values for $M_{L}, f_{\mathrm{c}}$, and $h$ into Eq. 10 to estimate $K_{\mathrm{d}}$, enters the tabulated value for $r_{1}$ into Eq. 8 to estimate $F_{\mathrm{r}}$, enters values for $F_{\mathrm{r}}$ and $h$ into Eq. 7a or $7 \mathrm{~b}$ for $K_{\mathrm{cb} \text { full }}$, and then enters the values for $K_{\mathrm{cb} \text { full }}, K_{\mathrm{d}}$ and $K_{\mathrm{c} \min }$ into Eq. 5a to determine $K_{\mathrm{cb}}$ ini or $K_{\mathrm{cb}}$ end. Values for the midseason $K_{\mathrm{cb}}$ mid are estimated similarly, although the value for fraction of cover, $f_{c}$, can vary widely, depending on the tree density, age and degree and type of pruning. The values given for $f_{\mathrm{c}}$ in Table 2 for the initial period reflect the amount of effective 'transpiring' surface at the time that $K_{\mathrm{c}}$ ini occurs. For many orchard crops, the initial period may represent the time of flowering or late 
Fig. $6 K_{\mathrm{c}}$ versus $f_{\mathrm{c}}$ for seven vegetable crops in California reported by Grattan et al. (1998) $(\mathbf{a}-\mathbf{g})$ and tomatoes in California by Hanson and May (2006) (h), showing data and regression equations by Grattan et al. and Hanson and May (2006) with $K_{\mathrm{c}}$ estimated using Eqs. 6, 7a, and 10. The small black symbols represent measured data
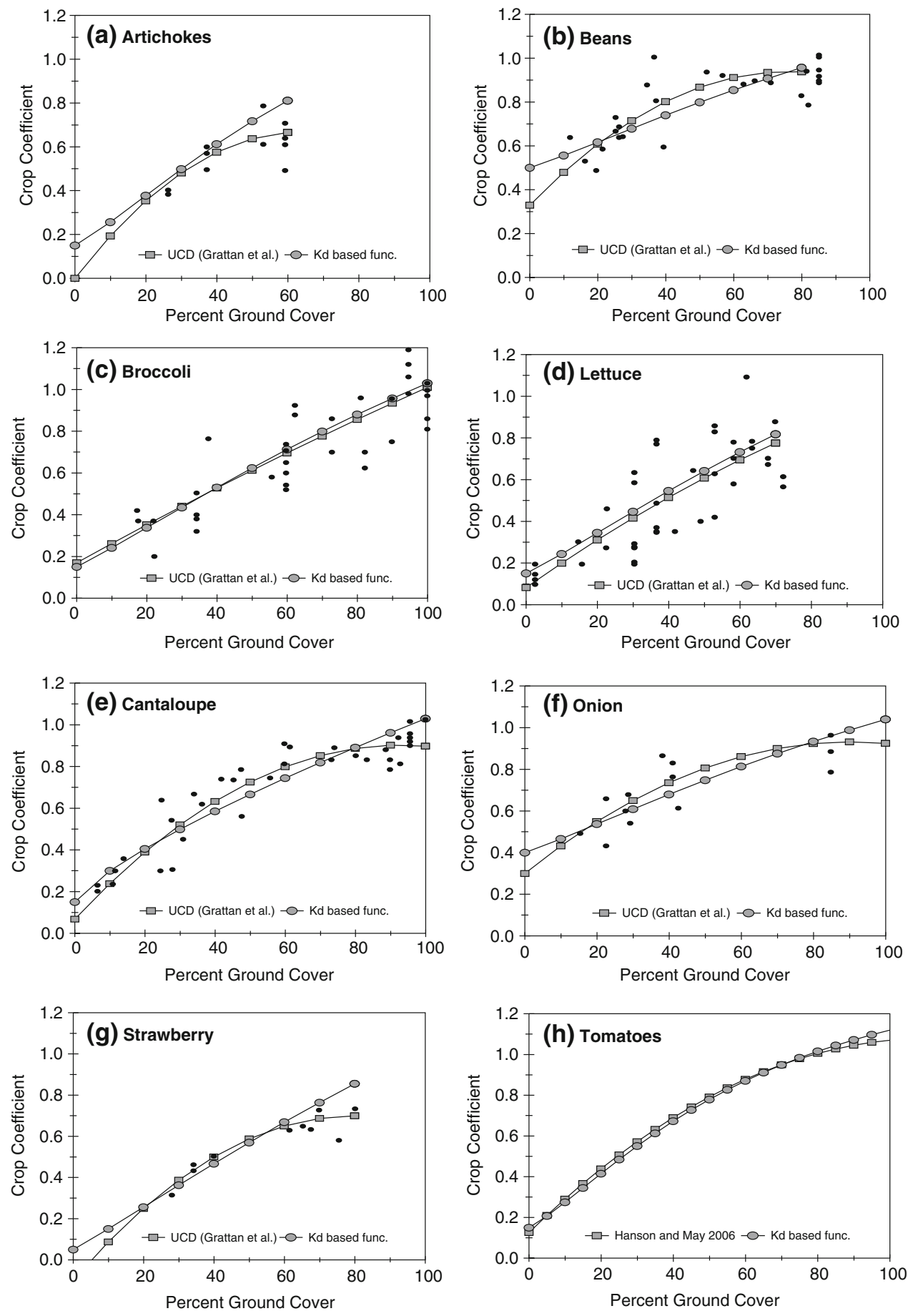

dormancy prior to leaf development. That period, and the period of development prior to the midseason period, may be relatively short.

If a ground-cover is present in the orchard system, then Eq. $5 \mathrm{~b}$ is applied to determine $K_{\mathrm{cb}}$, where the $K_{\mathrm{cb}}$ cover represents the basal $K_{\mathrm{cb}}$ for the ground cover in the absence of the orchard. The value for $K_{\mathrm{cb}}$ cover will range widely depending on the density, type and management of the ground cover.
In the case of estimating values for the single (mean) $K_{\mathrm{c}}$, the $K_{\text {soil }}$ parameter in Eq. 6 can be estimated using the Figures 29 and 30 of FAO-56 (Allen et al. 1998), Eq. 18 of Allen et al. 2005b, or by averaging a daily estimate of soil evaporation via a daily soil water balance, such as the $K_{\mathrm{e}}$ computation of FAO-56 (Allen et al. 1998, 2005a).

Table 3 contains entries for grass $\mathrm{ET}_{\mathrm{o}}$-based $K_{\mathrm{c}}$ ini, $K_{\mathrm{c} \text { mid }}, K_{\mathrm{c} \text { end }}, K_{\mathrm{cb} \text { ini }}, K_{\mathrm{cb} \text { mid }}$, and $K_{\mathrm{cb} \text { end }}$ for a number of 


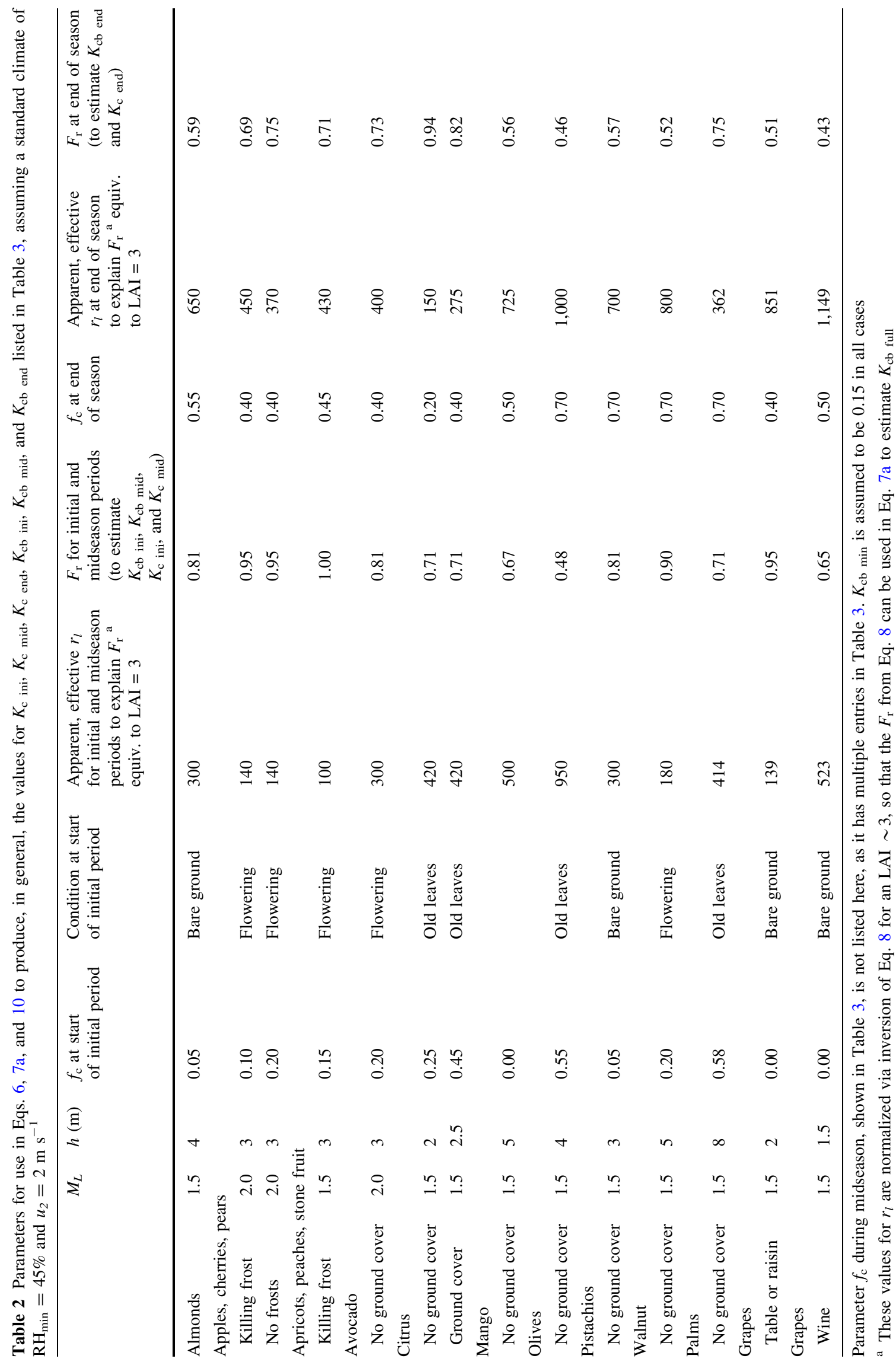


Table 3 Values for $K_{\mathrm{c} \text { ini }}, K_{\mathrm{c} \text { mid }}, K_{\mathrm{c} \text { end }}, K_{\mathrm{cb} \text { ini }}, K_{\mathrm{cb} \text { mid }}$, and $K_{\mathrm{cb} \text { end }}$ for a standard climate of $\mathrm{RH}_{\min }=45 \%$ and $u_{2}=2 \mathrm{~m} \mathrm{~s}^{-1}$ as expanded from FAO-56 for a range of values for $f_{\mathrm{c}}$ during midseason and using parameter values in Table 2 in Eqs. $5 \mathrm{a}-10$

\begin{tabular}{|c|c|c|c|c|c|c|}
\hline Crop & $\mathrm{K}_{\mathrm{c} \text { ini }}^{\mathrm{a}}$ & $\mathrm{K}_{\mathrm{c} \text { mid }}$ & $\mathrm{K}_{\mathrm{c} \text { end }}$ & $\mathrm{K}_{\mathrm{cb} \text { ini }}$ & $\mathrm{K}_{\mathrm{cb} \text { mid }}$ & $\mathrm{K}_{\mathrm{cb} \text { end }}$ \\
\hline \multicolumn{7}{|l|}{ Fruit trees } \\
\hline \multicolumn{7}{|l|}{ Almonds } \\
\hline \multicolumn{7}{|l|}{ No ground cover } \\
\hline High density $\left(f_{c \text { eff }}=0.7\right)$ & 0.40 & 1.00 & $0.70^{\mathrm{b}}$ & 0.20 & 0.95 & $0.65^{\mathrm{b}}$ \\
\hline Med. density $\left(f_{c \text { eff }}=0.5\right)^{c}$ & 0.40 & 0.85 & $0.60^{\mathrm{b}}$ & 0.20 & 0.80 & $0.55^{\mathrm{b}}$ \\
\hline Low dens./young $\left(f_{\mathrm{c} \text { eff }}=0.25\right)$ & 0.35 & 0.50 & $0.40^{\mathrm{b}}$ & 0.15 & 0.45 & $0.35^{\mathrm{b}}$ \\
\hline \multicolumn{7}{|l|}{ Active ground cover } \\
\hline High density $\left(f_{c \text { eff }}=0.7\right)^{\mathrm{j}}$ & 0.85 & 1.05 & $0.85^{\mathrm{b}}$ & 0.75 & 1.00 & $0.80^{\mathrm{b}}$ \\
\hline Med. density $\left(\mathrm{f}_{\mathrm{c} \text { eff }}=0.5\right)$ & 0.85 & 1.00 & $0.85^{\mathrm{b}}$ & 0.75 & 0.95 & $0.80^{\mathrm{b}}$ \\
\hline Low dens./young $\left(f_{c \text { eff }}=0.25\right)$ & 0.85 & 0.95 & $0.85^{\mathrm{b}}$ & 0.75 & 0.90 & $0.80^{\mathrm{b}}$ \\
\hline \multicolumn{7}{|l|}{ Apples, cherries, pears } \\
\hline \multicolumn{7}{|l|}{ No ground cover } \\
\hline High density $\left(f_{c \text { eff }}=0.7\right)$ & 0.50 & 1.15 & $0.80^{\mathrm{b}}$ & 0.30 & 1.10 & $0.75^{\mathrm{b}}$ \\
\hline Med. density $\left(f_{c \text { eff }}=0.5\right)^{c}$ & 0.50 & 1.05 & $0.75^{\mathrm{b}}$ & 0.30 & $1.00^{\mathrm{d}}$ & $0.70^{\mathrm{b}}$ \\
\hline Low dens./young $\left(f_{c \text { eff }}=0.25\right)$ & 0.40 & 0.70 & $0.55^{\mathrm{b}}$ & 0.25 & 0.65 & $0.50^{\mathrm{b}}$ \\
\hline \multicolumn{7}{|l|}{ Active ground cover } \\
\hline Killing frost, $h$. dens. $\left(f_{c \text { eff }}=0.7\right)^{j}$ & 0.50 & 1.20 & $0.85^{\mathrm{b}}$ & 0.40 & 1.15 & $0.80^{\mathrm{b}}$ \\
\hline Killing frost, m. dens. $\left(f_{c \text { eff }}=0.5\right)^{c}$ & 0.50 & 1.15 & $0.85^{\mathrm{b}}$ & 0.40 & 1.10 & $0.80^{\mathrm{b}}$ \\
\hline Killing frost, 1 . dens. $\left(f_{c \text { eff }}=0.25\right)$ & 0.50 & 1.05 & $0.85^{\mathrm{b}}$ & 0.40 & 1.00 & $0.80^{\mathrm{b}}$ \\
\hline No frosts, $h$. dens. $\left(f_{c \text { eff }}=0.7\right)$ & 0.85 & 1.20 & $0.85^{\mathrm{b}}$ & 0.75 & 1.15 & $0.80^{\mathrm{b}}$ \\
\hline No frosts, $m$. dens. $\left(f_{c \text { eff }}=0.5\right)^{c}$ & 0.85 & 1.15 & $0.85^{\mathrm{b}}$ & 0.75 & 1.10 & $0.80^{\mathrm{b}}$ \\
\hline No frosts, 1. dens. $\left(f_{c \text { eff }}=0.25\right)$ & 0.85 & 1.05 & $0.85^{\mathrm{b}}$ & 0.75 & 1.00 & $0.80^{\mathrm{b}}$ \\
\hline \multicolumn{7}{|l|}{ Apricots, peaches, stone fruit ${ }^{\mathrm{e}}$} \\
\hline \multicolumn{7}{|l|}{ No ground cover } \\
\hline Super density $\left(f_{c \text { eff }}=0.9\right)^{f}$ & 0.50 & 1.20 & $0.85^{\mathrm{b}}$ & 0.30 & 1.15 & $0.80^{\mathrm{b}}$ \\
\hline High density $\left(f_{c \text { eff }}=0.7\right)^{\mathrm{g}}$ & 0.50 & 1.15 & $0.80^{\mathrm{b}}$ & 0.30 & 1.10 & $0.75^{\mathrm{b}}$ \\
\hline Med. density $\left(f_{c \text { eff }}=0.5\right)^{c}$ & 0.45 & 1.0 & $0.70^{\mathrm{b}}$ & 0.25 & 0.95 & $0.65^{\mathrm{b}}$ \\
\hline Low dens./young $\left(f_{c \text { eff }}=0.25\right)^{\mathrm{h}}$ & 0.40 & 0.60 & $0.45^{\mathrm{b}}$ & 0.20 & 0.55 & $0.40^{\mathrm{b}}$ \\
\hline \multicolumn{7}{|l|}{ Active ground cover } \\
\hline Killing frost, s. dens. $\left(f_{c \text { eff }}=0.9\right)^{j}$ & 0.50 & 1.25 & $0.85^{\mathrm{b}}$ & 0.40 & 1.20 & $0.80^{\mathrm{b}}$ \\
\hline Killing frost, $h$. dens. $\left(f_{c \text { eff }}=0.7\right)^{c}$ & 0.50 & 1.20 & $0.85^{\mathrm{b}}$ & 0.40 & 1.15 & $0.80^{\mathrm{b}}$ \\
\hline Killing frost, $\mathrm{m}$. dens. $\left(\mathrm{f}_{\mathrm{c} \text { eff }}=0.5\right)$ & 0.50 & 1.15 & $0.85^{\mathrm{b}}$ & 0.40 & 1.10 & $0.80^{\mathrm{b}}$ \\
\hline Killing frost, 1 . dens. $\left(f_{c \text { eff }}=0.25\right)$ & 0.50 & 1.00 & $0.85^{\mathrm{b}}$ & 0.40 & 0.95 & $0.80^{\mathrm{b}}$ \\
\hline No frosts, s. dens. $\left(f_{c \text { eff }}=0.9\right)$ & 0.80 & 1.25 & $0.85^{\mathrm{b}}$ & 0.70 & 1.20 & $0.80^{\mathrm{b}}$ \\
\hline No frosts, h. dens. $\left(f_{c \text { eff }}=0.7\right)^{c}$ & 0.80 & 1.20 & $0.85^{\mathrm{b}}$ & 0.70 & 1.15 & $0.80^{\mathrm{b}}$ \\
\hline No frosts, $m$. dens. $\left(f_{c \text { eff }}=0.5\right)$ & 0.80 & 1.15 & $0.85^{\mathrm{b}}$ & 0.70 & 1.10 & $0.80^{\mathrm{b}}$ \\
\hline No frosts, 1 . dens. $\left(f_{c \text { eff }}=0.25\right)$ & 0.80 & 1.00 & $0.85^{\mathrm{b}}$ & 0.70 & 0.95 & $0.80^{\mathrm{b}}$ \\
\hline \multicolumn{7}{|l|}{ Avocado } \\
\hline \multicolumn{7}{|l|}{ No ground cover } \\
\hline High density $\left(f_{c \text { eff }}=0.7\right)$ & 0.50 & 1.00 & 0.90 & 0.30 & 0.95 & 0.85 \\
\hline Med. density $\left(f_{c \text { eff }}=0.5\right)^{c}$ & 0.50 & 0.90 & 0.80 & 0.30 & 0.85 & 0.80 \\
\hline Low dens./young $\left(f_{\mathrm{c} \text { eff }}=0.25\right)$ & 0.40 & 0.65 & 0.60 & 0.25 & 0.60 & 0.50 \\
\hline \multicolumn{7}{|l|}{ Active ground cover } \\
\hline High density $\left(f_{c \text { eff }}=0.7\right)^{\mathrm{j}}$ & 0.85 & 1.05 & 0.95 & 0.75 & 1.00 & 0.90 \\
\hline Med. density $\left(f_{c}\right.$ eff $\left.=0.5\right)$ & 0.85 & 1.00 & 0.95 & 0.75 & 0.95 & 0.90 \\
\hline Low dens./young $\left(f_{\mathrm{c} \text { eff }}=0.25\right)$ & 0.85 & 0.95 & 0.90 & 0.75 & 0.90 & 0.85 \\
\hline
\end{tabular}


Table 3 continued

\begin{tabular}{|c|c|c|c|c|c|c|}
\hline Crop & $\mathrm{K}_{\mathrm{c} \text { ini }}^{\mathrm{a}}$ & $\mathrm{K}_{\mathrm{c} \text { mid }}$ & $\mathrm{K}_{\mathrm{c} \text { end }}$ & $\mathrm{K}_{\mathrm{cb} \text { ini }}$ & $\mathrm{K}_{\mathrm{cb} \text { mid }}$ & $\mathrm{K}_{\mathrm{cb} \text { end }}$ \\
\hline \multicolumn{7}{|l|}{ Citrus } \\
\hline \multicolumn{7}{|l|}{ No ground cover } \\
\hline High density $\left(f_{c \text { eff }}=0.7\right)^{i}$ & 0.95 & 0.90 & 0.90 & 0.85 & 0.85 & 0.85 \\
\hline Med. density $\left(\mathrm{f}_{\mathrm{c} \text { eff }}=0.5\right)$ & 0.80 & 0.75 & 0.75 & 0.70 & 0.70 & 0.70 \\
\hline Low dens./young $\left(\mathrm{f}_{\mathrm{c} \text { eff }}=0.25\right)$ & 0.55 & 0.50 & 0.50 & 0.45 & 0.45 & 0.45 \\
\hline \multicolumn{7}{|l|}{ Active ground cover } \\
\hline High density $\left(f_{c \text { eff }}=0.7\right)^{\mathrm{j}, \mathrm{k}}$ & 1.00 & 0.95 & 0.95 & 0.90 & 0.90 & 0.90 \\
\hline Med. density $\left(\mathrm{f}_{\mathrm{c} \text { eff }}=0.5\right)$ & 0.95 & 0.95 & 0.95 & 0.85 & 0.90 & 0.90 \\
\hline Low dens./young $\left(f_{\mathrm{c} \text { eff }}=0.25\right)$ & 0.90 & 0.90 & 0.90 & 0.80 & 0.85 & 0.85 \\
\hline \multicolumn{7}{|l|}{ Mango } \\
\hline \multicolumn{7}{|l|}{ No ground cover } \\
\hline High density $\left(f_{c \text { eff }}=0.7\right)^{1}$ & 0.35 & 0.90 & 0.75 & 0.25 & 0.85 & 0.70 \\
\hline Med. density $\left(\mathrm{f}_{\mathrm{c} \text { eff }}=0.5\right)$ & 0.35 & 0.75 & 0.60 & 0.25 & 0.70 & 0.55 \\
\hline Low dens./young $\left(\mathrm{f}_{\mathrm{c} \text { eff }}=0.25\right)$ & 0.30 & 0.45 & 0.40 & 0.20 & 0.40 & 0.35 \\
\hline \multicolumn{7}{|l|}{ Olives } \\
\hline \multicolumn{7}{|l|}{ No ground cover } \\
\hline High density $\left(f_{c \text { eff }}=0.7\right)^{\mathrm{c}, \mathrm{m}}$ & 0.65 & 0.70 & 0.60 & 0.55 & 0.65 & 0.55 \\
\hline Med. density $\left(\mathrm{f}_{\mathrm{c} \text { eff }}=0.5\right)^{\mathrm{n}}$ & 0.60 & 0.60 & 0.55 & 0.50 & 0.55 & 0.50 \\
\hline Low dens./young $\left(f_{\mathrm{c} \text { eff }}=0.25\right)^{\circ}$ & 0.40 & 0.40 & 0.35 & 0.30 & 0.35 & 0.30 \\
\hline V. low dens./young $\left(f_{c \text { eff }}=0.05\right)^{\circ}$ & 0.30 & 0.25 & 0.25 & 0.20 & 0.20 & 0.20 \\
\hline \multicolumn{7}{|l|}{ Active ground cover } \\
\hline High density $\left(f_{c} \text { eff }=0.7\right)^{j}$ & 0.80 & 0.75 & 0.75 & 0.70 & 0.70 & 0.70 \\
\hline Med. density $\left(\mathrm{f}_{\mathrm{c} \text { eff }}=0.5\right)$ & 0.80 & 0.75 & 0.75 & 0.70 & 0.70 & 0.70 \\
\hline Low dens./young $\left(f_{\mathrm{c} \text { eff }}=0.25\right)$ & 0.80 & 0.75 & 0.75 & 0.70 & 0.70 & 0.70 \\
\hline V. low dens./young $\left(f_{c \text { eff }}=0.05\right)$ & 0.80 & 0.75 & 0.75 & 0.70 & 0.70 & 0.70 \\
\hline \multicolumn{7}{|l|}{ Pistachios } \\
\hline \multicolumn{7}{|l|}{ No ground cover } \\
\hline High density $\left(\mathrm{f}_{\mathrm{c} \text { eff }}=0.7\right)$ & 0.40 & 1.00 & 0.70 & 0.30 & 0.95 & 0.65 \\
\hline Med. density $\left(f_{c \text { eff }}=0.5\right)$ & 0.35 & 0.85 & 0.60 & 0.25 & 0.80 & 0.55 \\
\hline Low dens./young $\left(f_{\mathrm{c} \text { eff }}=0.25\right)$ & 0.30 & 0.50 & 0.40 & 0.20 & 0.45 & 0.35 \\
\hline \multicolumn{7}{|l|}{ Active ground cover } \\
\hline High density $\left(\mathrm{f}_{\mathrm{c} \text { eff }}=0.7\right)$ & 0.80 & 1.00 & 0.75 & 0.70 & 0.95 & 0.70 \\
\hline Med. density $\left(f_{c \text { eff }}=0.5\right)$ & 0.80 & 1.00 & 0.75 & 0.70 & 0.95 & 0.70 \\
\hline Low dens./young $\left(f_{\mathrm{c} \text { eff }}=0.25\right)$ & 0.80 & 0.85 & 0.75 & 0.70 & 0.80 & 0.70 \\
\hline \multicolumn{7}{|l|}{ Walnut Orchard } \\
\hline \multicolumn{7}{|l|}{ No ground cover } \\
\hline High density $\left(f_{c \text { eff }}=0.7\right)$ & 0.50 & 1.10 & $0.65^{\mathrm{b}}$ & 0.40 & 1.05 & $0.60^{\mathrm{b}}$ \\
\hline Med. density $\left(\mathrm{f}_{\mathrm{c} \text { eff }}=0.5\right)$ & 0.45 & 0.90 & $0.60^{\mathrm{b}}$ & 0.35 & 0.85 & $0.55^{\mathrm{b}}$ \\
\hline Low dens./young $\left(f_{\mathrm{c} \text { eff }}=0.25\right)$ & 0.35 & 0.55 & $0.40^{\mathrm{b}}$ & 0.25 & 0.50 & $0.35^{\mathrm{b}}$ \\
\hline \multicolumn{7}{|l|}{ Active ground cover } \\
\hline High density $\left(f_{c \text { eff }}=0.7\right)^{\mathrm{j}}$ & 0.85 & 1.15 & $0.85^{\mathrm{b}}$ & 0.75 & 1.10 & $0.80^{\mathrm{b}}$ \\
\hline Med. density $\left(f_{c \text { eff }}=0.5\right)$ & 0.85 & 1.10 & $0.85^{\mathrm{b}}$ & 0.75 & 1.05 & $0.80^{\mathrm{b}}$ \\
\hline Low dens./young $\left(f_{c \text { eff }}=0.25\right)$ & 0.85 & 0.95 & $0.85^{\mathrm{b}}$ & 0.75 & 0.90 & $0.80^{\mathrm{b}}$ \\
\hline \multicolumn{7}{|l|}{ Palms (including date palms) } \\
\hline \multicolumn{7}{|l|}{ No ground cover } \\
\hline High density $\left(f_{c \text { eff }}=0.7\right)^{c}$ & 0.90 & 0.95 & 0.95 & 0.80 & 0.85 & 0.85 \\
\hline Med. density $\left(f_{c \text { eff }}=0.5\right)$ & 0.80 & 0.80 & 0.80 & 0.70 & 0.70 & 0.70 \\
\hline Low dens./young $\left(f_{\text {c eff }}=0.25\right)$ & 0.50 & 0.55 & 0.55 & 0.40 & 0.45 & 0.45 \\
\hline
\end{tabular}


Table 3 continued

\begin{tabular}{|c|c|c|c|c|c|c|}
\hline Crop & $\mathrm{K}_{\mathrm{c} \text { ini }}^{\mathrm{a}}$ & $\mathrm{K}_{\mathrm{c} \text { mid }}$ & $\mathrm{K}_{\mathrm{c} \text { end }}$ & $\mathrm{K}_{\mathrm{cb} \text { ini }}$ & $\mathrm{K}_{\mathrm{cb} \text { mid }}$ & $\mathrm{K}_{\mathrm{cb} \text { end }}$ \\
\hline V. low dens./young $\left(f_{c \text { eff }}=0.1\right)$ & 0.35 & 0.35 & 0.35 & 0.25 & 0.25 & 0.25 \\
\hline \multicolumn{7}{|l|}{ Active ground cover } \\
\hline High density $\left(f_{c \text { eff }}=0.7\right)$ & 0.95 & 0.95 & 0.95 & 0.85 & 0.90 & 0.90 \\
\hline Med. density $\left(f_{c \text { eff }}=0.5\right)$ & 0.90 & 0.90 & 0.90 & 0.80 & 0.85 & 0.85 \\
\hline Low dens./young $\left(\mathrm{f}_{\mathrm{c} \text { eff }}=0.25\right)$ & 0.85 & 0.85 & 0.85 & 0.75 & 0.80 & 0.80 \\
\hline V. low dens./young $\left(f_{c \text { eff }}=0.1\right)$ & 0.80 & 0.80 & 0.80 & 0.70 & 0.75 & 0.75 \\
\hline \multicolumn{7}{|l|}{ Grapes: table or raisin } \\
\hline \multicolumn{7}{|l|}{ No ground cover } \\
\hline High density $\left(f_{c \text { eff }}=0.7\right)^{f}$ & 0.30 & 1.10 & $0.85^{\mathrm{b}}$ & 0.20 & 1.05 & $0.80^{\mathrm{b}}$ \\
\hline Med. density $\left(f_{c \text { eff }}=0.5\right)^{c}$ & 0.30 & 0.95 & $0.75^{\mathrm{b}}$ & 0.20 & 0.90 & $0.70^{\mathrm{b}}$ \\
\hline Low/young $\left(f_{\mathrm{c} \text { eff }}=0.25\right)$ & 0.30 & 0.60 & $0.50^{\mathrm{b}}$ & 0.20 & 0.55 & $0.45^{\mathrm{b}}$ \\
\hline \multicolumn{7}{|l|}{ Grapes: wine } \\
\hline \multicolumn{7}{|l|}{ No ground cover } \\
\hline High density $\left(f_{c \text { eff }}=0.7\right)$ & 0.30 & $0.75^{\mathrm{p}}$ & $0.60^{\text {bp }}$ & 0.20 & $0.70^{\mathrm{p}}$ & $0.55^{\text {bp }}$ \\
\hline Med. density $\left(f_{c \text { eff }}=0.5\right)^{c}$ & 0.30 & $0.70^{\mathrm{p}}$ & $0.55^{\mathrm{bp}}$ & 0.20 & $0.65^{\mathrm{p}}$ & $0.50^{\mathrm{bp}}$ \\
\hline Low/young $\left(f_{\mathrm{c} \text { eff }}=0.25\right)$ & 0.30 & $0.45^{\mathrm{p}}$ & $0.40^{\mathrm{bp}}$ & 0.25 & $0.40^{\mathrm{p}}$ & $0.30^{\mathrm{bp}}$ \\
\hline
\end{tabular}

Many of the values for $f_{\mathrm{c}}$ and $K_{\mathrm{c} \text { mid }}$ are compared to values reported in specific literature (after Allen et al. 2007a)

a These are general values for $K_{\mathrm{c}}$ ini under typical irrigation management and soil wetting. For frequent wettings such as with high frequency sprinkle irrigation or daily rainfall, these values may increase substantially and may approach $1.0-1.2 . K_{\mathrm{c}}$ ini is a function of wetting interval and potential evaporation rate during the initial and development periods and is more accurately estimated using Figures 29 and 30 of FAO-56, an equation from Allen et al. (2005b), or using the dual $K_{\mathrm{cb} \text { ini }}+K_{\mathrm{e}}$ calculation

b These $K_{\mathrm{c} \text { end }}$ values represent $K_{\mathrm{c}}$ prior to leaf drop. After leaf drop, $K_{\mathrm{c} \text { end }} \approx 0.20$ for bare, dry soil or dead ground cover and $K_{\mathrm{c} \text { end }} \approx 0.50-$ 0.80 for actively growing ground cover

c The values in this row are similar to the entry in FAO-56 (Allen et al. 1998)

${ }^{\mathrm{d}}$ For pears having $\mathrm{f}_{\mathrm{c} \text { eff }}=0.5$, Girona et al. (2003) measured $K_{\mathrm{cb} \text { mid }}=0.85$, which is estimated using Eq.5a and 10 with $K_{\mathrm{cb}}$ full $=1.1$ and $M_{L}=1.5$

e Stone fruit category applies to peaches, apricots, pears, plums and pecans

${ }^{\mathrm{f}}$ The values in this row are similar to those by Johnson et al. (2005)

$\mathrm{g}$ The values in this row are derived from Girona et al. (2005)

$\mathrm{h}$ The values in this row are similar to those by Paço et al. (2006)

i The values for citrus are about $20 \%$ higher than those reported in FAO-56

${ }^{\mathrm{j}}$ For non-active or only moderately active ground cover (active indicates green and growing ground cover with LAI $>$ about 2 ), $K_{\mathrm{c}}$ should be weighted between $K_{\mathrm{c}}$ for no ground cover and $K_{\mathrm{c}}$ for active ground cover, with the weighting based on the "greenness" and approximate leaf area of the ground cover

$\mathrm{k}$ The values in this row are similar to those by Rogers et al. (1983) for citrus in Florida having Bahia grass cover

${ }^{1}$ The values in this row are derived from de Azevedo et al. (2003)

${ }^{\mathrm{m}}$ Pastor and Orgaz (1994) found monthly $K_{\mathrm{c}}$ for olive orchards having $f_{\mathrm{c}} \sim 0.6$ similar to the values shown, except that $K_{\mathrm{c}}$ mid $=0.45$, and using $K_{\mathrm{c}}$ during the winter ("off season") in December-February $=0.50$

${ }^{\mathrm{n}}$ The values in this row are similar to those by Villalobos et al. (2000) when $f_{\mathrm{c}}$ eff of $\sim 0.3-0.4$ are applied

${ }^{\circ}$ The values in this row are derived from Testi et al. (2004)

p These $K_{\mathrm{c} \text { mid }}$ and $K_{\mathrm{c} \text { end }}$ values include an implicit $K_{\mathrm{s}}$ (stress) factor of about 0.7 (see Eqs. 1 and 2), which is common for wine production. In practice, a $K_{\mathrm{s}}$ model and estimate should be applied where $K_{\mathrm{s}}$ can range from 0.5 to 1.0. Under no stress, the $K_{\mathrm{c}}$ mid and $K_{\mathrm{c}}$ end for wine grapes may equal that for table grapes, depending on plant density, age, and pruning structure

orchard crops and grapes as expanded from the FAO-56 tables by Allen et al. $(2007 \mathrm{a}, \mathrm{b})$. The values for $K_{\mathrm{c}}$ reflect a standard climate having $\mathrm{RH}_{\min }=45 \%$ and $u_{2}=$ $2 \mathrm{~m} \mathrm{~s}^{-1}$. The $K_{\mathrm{c}}$ values cover a range of values for $f_{\mathrm{c}}$ during midseason that contain entries that follow $f_{\mathrm{c}}$ and $K_{\mathrm{c}}$ taken from literature, and where the $K_{\mathrm{c}}$ values can be largely produced using parameter values listed in Table 4 using Eqs. 5a-10.

Values for potential $K_{\mathrm{cb} \text { full }}$ were estimated from Eq. 7a using $h$ and represent $K_{\mathrm{cb}}$ full at maximum $f_{\mathrm{c}}$. In nearly all cases, the potential $K_{\mathrm{cb} \text { full }}$ was 1.2 for the orchard crops for the $\mathrm{ET}_{\mathrm{o}}$ basis. 


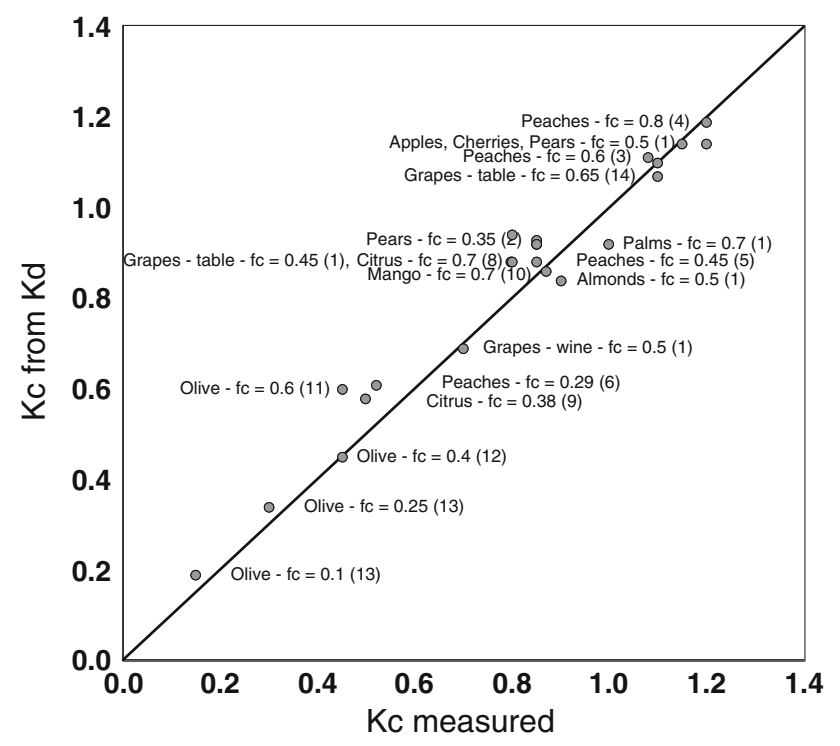

Fig. $7 K_{\mathrm{cb} \text { mid }}$ or $K_{\mathrm{c} \text { mid }}$ estimated using Eqs. 5a-10 and parameters in Tables 2 and 5 versus $K_{\mathrm{cb} \text { mid }}$ or $K_{\mathrm{c} \mathrm{mid}}$ as reported for various orchard and grape measurements in the literature for midseason growing conditions

\section{Comparison of $K_{\mathrm{c}}$ from Eq. $5 \mathrm{a}$ or 6 based on $K_{\mathrm{d}}$ from Eq. 10 with reported data for orchards and grapes}

Estimates for $K_{\mathrm{cb} \text { mid }}$ or $K_{\mathrm{c} \text { mid }}$ based on Eqs. 5a-10. and parameters in Tables 2, 4, and 5 are plotted in Fig. 7 against values for $K_{\mathrm{cb} \text { mid }}$ or $K_{\mathrm{c} \text { mid }}$ as reported for various orchard and grape measurements in the literature as cited below. The estimates for $K_{\mathrm{cb} \text { mid }}$ or $K_{\mathrm{c} \text { mid }}$ utilized $f_{\mathrm{c}}$ and $h$ similar to those reported for the studies. The reported studies were all for essentially bare soil surface, so that Eq. 5a was used rather than Eq. 5b. In nearly all cases, the estimated $K_{\mathrm{c}}$ agreed relatively closely with measured, indicating that the series of equations and parameters from Table 2 may be useful to estimate $K_{\mathrm{c}}$ for other conditions. The values for $r_{1}$ listed in Table 2 and that were used in Eq. 8 to estimate $F_{\mathrm{r}}$ that was in turn used in Eq. 7a to estimate $K_{\mathrm{cb} \text { full }}$, were specifically derived for each crop, based on reported $K_{\mathrm{cb}}$, so that the precautions and limitations previously noted should apply.

The literature sources cited in Fig. 7 are (1) Allen et al. (1998), (2) Girona et al. (2003), (3) Girona et al. (2005), (4) Johnson et al. (2005) (for microspray irrigation and dense, wet vegetation), (5) Ayars et al. (2003), (6) Paço et al. (2006), (7) FAO56 (Allen et al. 1998), (8) Consoli et al. (2005), (9) Alba et al. (2006), (10) de Azevedo et al. (2003), (11) Pastor and Orgaz (1994), (12) Villalobos et al. (2000) $\left(f_{\mathrm{c}}=0.4\right)$, (13) Testi et al. (2004), and (14) Allen et al. (1998).

The relationship between $K_{\mathrm{c}}$ and $f_{\mathrm{c}}$ established by Eqs. $5 \mathrm{a}-10$ is not singular but varies with crop height, relative stomatal resistance $\left(r_{l}\right)$, and in some cases, the background soil evaporation. The nonsingularity is demonstrated in Fig. 8 where measured $K_{\mathrm{c}}$ is plotted as a function of reported $f_{\mathrm{c}}$. The relatively large degree of scatter in the figure suggests that both height and stomatal control impact the value for $K_{\mathrm{c}}$ and should be considered during estimation.

\section{Applications of Eqs. 5a and 10 for $K_{\mathrm{c}}$ to natural vegetation}

Ringersma and Sikking (2001) applied equations similar to Eqs. 5a, 7a, and 9 to estimate ET from Sahelian vegetation barriers. They found Eq. 7a to overestimate $K_{\mathrm{cb}}$ full, even with adjustment using $F_{\mathrm{r}}$ from Eq. 8, but found Eq. 9 to produce representative estimates when combined with Eq. 5a. Ringersma and Sikking suggested distinction between $\mathrm{C} 3$ and $\mathrm{C} 4$ photosynthetic behavior for LAI and $f_{\mathrm{c}}$ based estimation, since $\mathrm{C} 4$ vegetation can have limited stomatal control. Descheemaeker et al. (2007) applied equations similar to Eqs. 5a, 6, 7a, and 9 to savannah vegetation in Ethiopia, and found good agreement between estimated ET and ET determined gravimetrically. Vegetation types ranged from sparse, grazed grasses to full forest canopy.

\section{Summary and Conclusions}

The FAO-56 procedure for estimating the crop coefficient $K_{\mathrm{c}}$ as a function of fraction of ground cover and crop height has been formalized in this study using a density coefficient $K_{\mathrm{d}} . K_{\mathrm{d}}$ is multiplied by a $K_{\mathrm{c}}$ representing full cover conditions, $K_{\mathrm{cb}}$ full, to produce $K_{\mathrm{cb}}$ representing the actual conditions of ground coverage. $K_{\mathrm{cb}}$ full is estimated primarily as a function of crop height. $K_{\mathrm{cb} \text { full }}$ can be adjusted for tree crops by multiplying by a reduction factor estimated using a mean leaf stomatal resistance term. The estimate for basal crop coefficient, $K_{\mathrm{cb}}$, is further modified for tree crops if some type of ground-cover exists understory or between trees. The single (mean) crop coefficient is adjusted using a $K_{\text {soil }}$ coefficient that represents background evaporation from wet soil.

The $K_{\mathrm{c}}$ estimation procedure was applied to the development periods for seven vegetable crops grown in California by Grattan et al. (1998). The estimates were compared to measured $K_{\mathrm{c}}$ as well as to polynomial equations fitted by Grattan. The estimation accuracy of the generalized method was nearly as good as the regressions fit by Grattan. The $K_{\mathrm{c}}$ estimation procedure was further applied to estimate $K_{\mathrm{c}}$ during midseason periods of horticultural crops (trees and vines) reported in the literature. Values for mean leaf stomatal resistance and the $F_{\mathrm{r}}$ reduction factor were derived that explain the literature $K_{\mathrm{c}}$ values. 


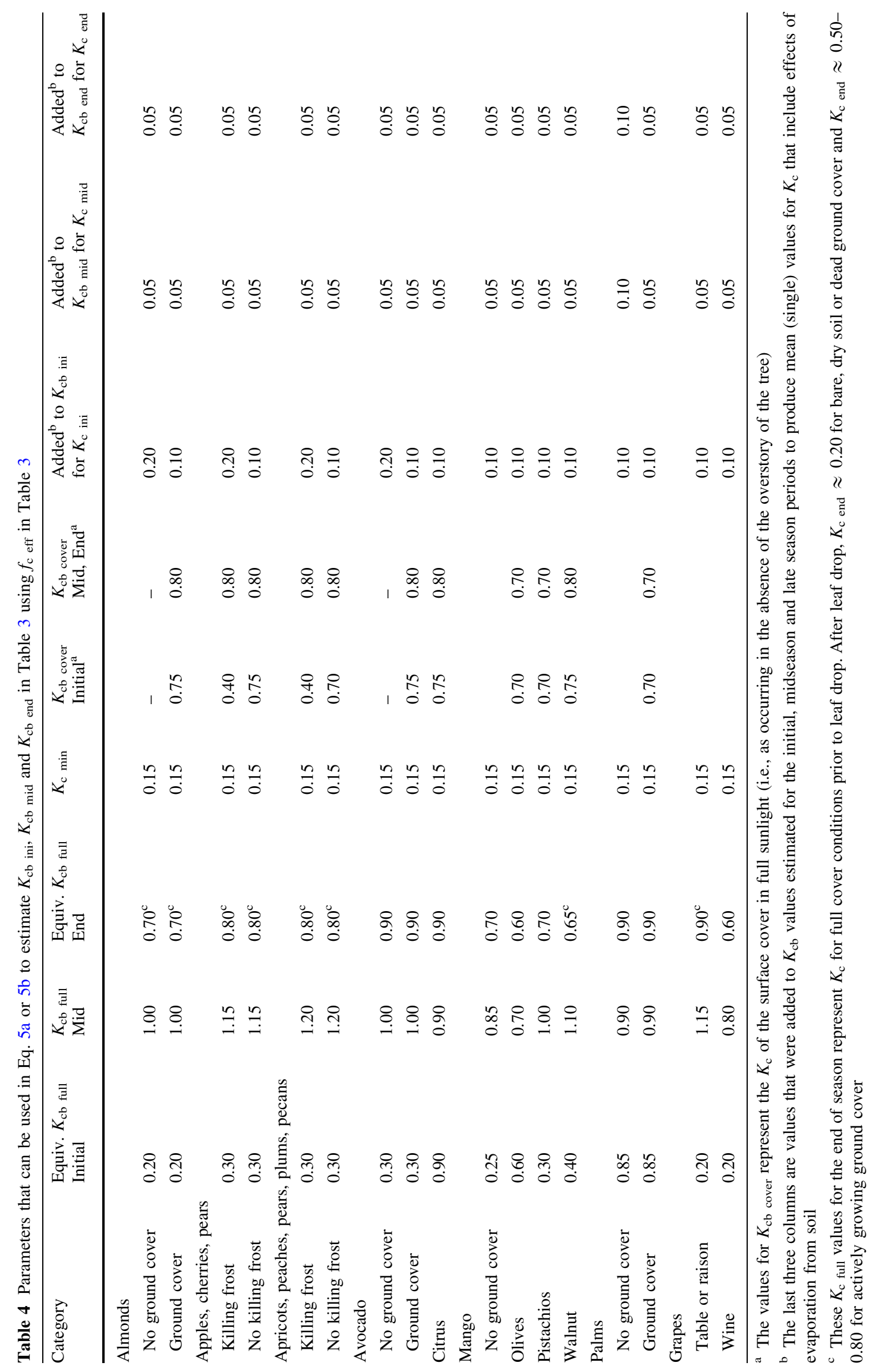


Table 5 Mean plant height, $h$, used in Eq. 7a and 10 for estimating $K_{\mathrm{cb} \text { ini }}, K_{\mathrm{cb} \text { mid }}$, and $K_{\mathrm{cb} \text { end }}$ in Table 3

\begin{tabular}{|c|c|c|c|c|c|}
\hline Category & $f_{\mathrm{c} \text { eff }}=0.05-0.1$ & $f_{\mathrm{c} \text { eff }}=0.25$ & $f_{\mathrm{c} \text { eff }}=0.5$ & $f_{\mathrm{c} \text { eff }}=0.7$ & $f_{\text {c eff }}=0.9$ \\
\hline Almonds & & 3 & 4 & 5 & \\
\hline Apples, Cherries, Pears & & 3 & 3 & 4 & \\
\hline Apricots, Peaches, Stone Fruit & & 2.5 & 3 & 3 & 3 \\
\hline Avocado & & 3 & 3 & 4 & \\
\hline Citrus & & 2 & 2.5 & 3 & \\
\hline Mango & & 4 & 4 & 5 & \\
\hline Olives & 2 & 3 & 4 & 4 & \\
\hline Pistachios & & 2 & 2.5 & 3 & \\
\hline Walnut & & 4 & 4 & 5 & \\
\hline Palms & 8 & 8 & 8 & 8 & \\
\hline \multicolumn{6}{|l|}{ Grapes } \\
\hline Table or raison & & 2 & 2 & 2 & \\
\hline Wine & & 1.5 & 1.5 & 1.5 & \\
\hline
\end{tabular}

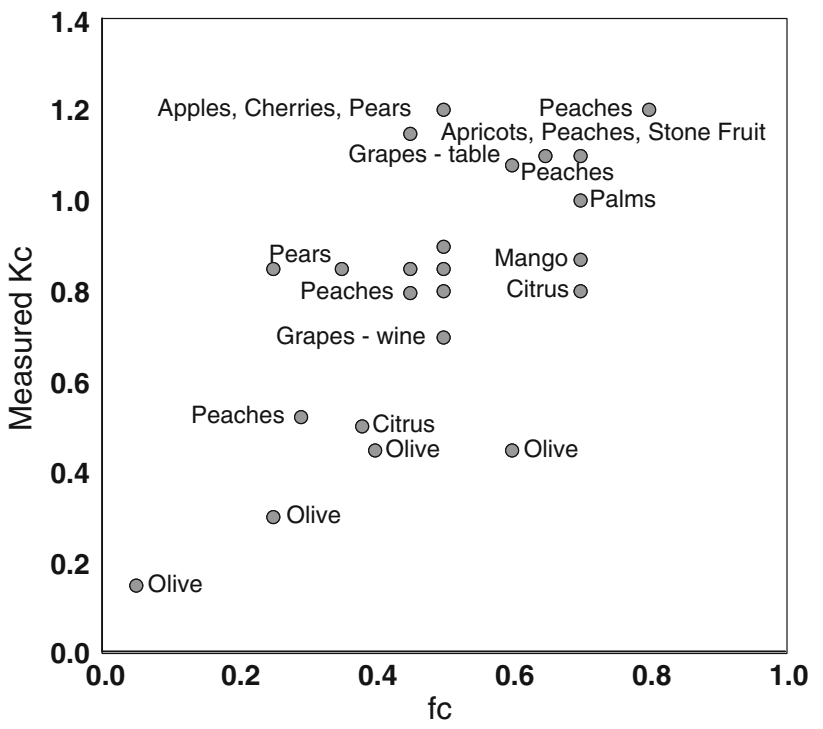

Fig. 8 Measured $K_{\mathrm{c}}$ reported in the literature plotted as a function of reported $f_{\mathrm{c}}$ for midseason conditions

The generalized method does not replace measurement of $K_{\mathrm{c}}$ for developing crop coefficient curves. However, it does provide a consistent means to assess measured values for reasonableness as well as providing a means to estimate change in values for $K_{\mathrm{c}}$ with change in fraction of ground covered by vegetation. This is important when estimating $K_{\mathrm{c}}$ for orchard crops which can vary widely in plant spacing, tree pruning, and age.

\section{References}

Alba I, Rodríguez PN, Pereira LS (2006) Irrigation scheduling simulation for citrus in Sicily to cope with water scarcity. In: Rossi G, Cancelliere A, Pereira LS, Oweis T, Shatanawi M, Zairi
A (eds) Tools for drought mitigation in Mediterranean regions. Kluwer, Dordrecht, pp 223-242

Allen RG, Howell TA Snyder RL (2009) Irrigation water requirements. In: Irrigation, chap 5, 6th edn. Irrigation Association (in press)

Allen RG, Pruitt WO, Businger JA, Fritschen LJ, Jensen ME, Quinn FH (1996) Evaporation and transpiration. In: Wootton et al (Task Com.) ASCE handbook of hydrology, chap 4, 2nd edn. American Society of Civil Engineers, New York, pp 125-252, $784 \mathrm{p}$

Allen RG, Pereira LS, Raes D, Smith M (1998) Crop evapotranspiration: guidelines for computing crop water requirements, Irrigation and Drainage Paper 56. United Nations FAO, Rome, 300 p. http://www.fao.org/docrep/X0490E/X0490E00.htm

Allen RG, Pereira LS, Smith M, Raes D, Wright JL (2005a) FAO-56 dual crop coefficient method for estimating evaporation from soil and application extensions. J Irrig Drain Eng ASCE 131(1):2-13

Allen RG, Pruitt WO, Raes D, Smith M, Pereira LS (2005b) Estimating evaporation from bare soil and the crop coefficient for the initial period using common soils information. J Irrig Drain Eng ASCE 131(1):14-23

Allen RG, Pruitt WO, Wright JL, Howell TA, Ventura F, Snyder R, Itenfisu D, Steduto P, Berengena J, Baselga Yrisarry J, Smith M, Pereira LS, Raes D, Perrier A, Alves I, Walter I, Elliott R (2006) A recommendation on standardized surface resistance for hourly calculation of reference ETo by the FAO56 Penman-Monteith method. Agric Water Manage 81:1-22

Allen RG, Wright JL, Pruitt WO, Pereira LS (2007a) Water requirements. In: Design and operation of farm irrigation systems, chap 8, 2nd edn. ASAE Monograph

Allen RG, Tasumi M, Morse A, Trezza R, Wright JL, Bastiaanssen W, Kramber W, Lorite I, Robison CW (2007b) Satellite-based energy balance for mapping evapotranspiration with internalized calibration (METRIC) - applications. J Irrig Drain Eng 133(4):395-406

ASCE-EWRI (2005) The ASCE standardized reference evapotranspiration equation. In: Allen RG, Walter IA, Elliott RL, Howell TA, Itenfisu D, Jensen ME, Snyder RL (eds) American Society of Civil Engineers, 69 p, App. A-F and Index

Ayars JE, Johnson RS, Phene CJ, Trout TJ, Clark DA, Mead RM (2003) Water use by drip-irrigated late-season peaches. Irrig Sci 22(3-4):187-194

Bodner G, Loiskandl W, Kaul H-P (2007) Cover crop evapotranspiration under semi-arid conditions using FAO dual crop 
coefficient method with water stress compensation. Agric Water Manage 93(3):85-98

Cholpankulov ED, Inchenkova OP, Paredes P, Pereira LS (2008) Cotton irrigation scheduling in Central Asia: model calibration and validation with consideration of groundwater contribution. Irrig Drain 57:516-532

Consoli, Simona G, D’Urso, Toscano A (2005) Remote sensing to estimate ET-fluxes and the performance of an irrigation district in southern Italy. Agric Water Manage 81(3):295-314

de Azevedo PV, da Silva BB, da Silva VPR (2003) Water requirements of irrigated mango orchards in northeast Brazil. Agric Water Manage 58:241-254

de Medeiros G, Arruda FB, Sakai E, Fujiwarab M (2001) The influence of crop canopy on evapotranspiration and crop coefficient of beans (Phaseolus vulgaris L.). Agric Water Manage 49(3):211-224

Descheemaeker K, Raes D, Allen RG, Nyssen J, Poesen J, Muys B, Haile M, Deckers J (2007) FAO-56 crop coefficients for semiarid natural vegetation in the northern Ethiopian highlands. Compl Report, Dept. Land Man., KUL Leuven, p 20

Doorenbos J, Pruitt WO (1977) Crop water requirements. Irrigation and Drainage Paper No. 24 (rev.) FAO, Rome, 144 p

Er-Raki S, Chehbouni A, Guemouria N, Duchemin B, Ezzahar J, Hadria R (2007) Combining FAO-56 model and ground-based remote sensing to estimate water consumptions of wheat crops in a semi-arid region. Agric Water Manage 87(1):41-54

Fereres E (ed) (1981) Drip irrigation management. Cooperative Extension, University of California, Berkeley, Leaflet No. 21259

Girona J, Marsal J, Mata M, del Campo J (2003) Pear crop coefficients obtained in a large weighing lysimeter. In: ISHS Acta Horticulturae 664: IV international symposium on irrigation of horticultural crops, $6 \mathrm{pp}$

Girona J, Gelly M, Mata M, Arbones A, Rufat J, Marsal J (2005) Peach tree response to single and combined deficit irrigation regimes in deep soils. Agric Water Manage 72:97-108

Goodwin I, Whitfield DM, Connor DJ (2006) Effects of tree size on water use of peach (Prunus persica L. Batsch). Irrig Sci 24(2):59-68

Grattan SR, Bowers W, Dong A, Snyder RL, Carroll JJ, George W (1998) New crop coefficients estimate water use of vegetables, row crops. Calif Agric 52(1):16-21

Greenwood KL, Lawson AR, Kelly KB (2009) The water balance of irrigated forages in northern Victoria, Austrália. Agric Water Manage 96(5):847-858

Hanson BR, May DM (2006) Crop evapotranspiration of processing tomato in the San Joaquin Valley of California, USA. Irrig Sci 24(4):211-221

Hernandez-Suarez M (1988) Modeling irrigation scheduling and its components and optimization of water delivery scheduling with dynamic programming and stochastic ETo data. $\mathrm{PhD}$ dissertation, University of California Davis, Davis

Howell TA, Evett SR, Tolk JA, Schneider AD (2004) Evapotranspiration of full-, deficit-irrigated, and dryland cotton on the Northern Texas High Plains. J Irrig Drain Eng ASCE 130(4):277-285

Hunsaker DJ (1999) Basal crop coefficients and water use for early maturity cotton. Trans ASAE 42(4):927-936

Hunsaker DJ, Pinter PJ Jr, Cai H (2002) Alfalfa basal crop coefficients for FAO-56 procedures in the desert regions of the southwestern U.S. Trans ASAE 45(6):1799-1815

Hunsaker DJ, Pinter PJ Jr, Barnes EM, Kimball BA (2003) Estimating cotton evapotranspiration crop coefficients with a multispectral vegetation index. Irrig Sci 22:95-104

Hunsaker DJ, Barnes EM, Clarke TR, Fitzgerald GJ, Pinter PJ Jr (2005) Cotton irrigation scheduling using remotely-sensed and Fao-56 basal crop coefficients. Trans ASAE 48(4):1395-1407
Jensen ME, Burman RD, Allen RG (ed) (1990) Evapotranspiration and irrigation water requirements. American Society of Civil Engineers Manual No. 70, $332 \mathrm{p}$

Johnson RS, Williams LE, Ayars JE, Trout TJ (2005) Weighing lysimeters aid study of water relations in tree and vine crops. Calif Agric 59(2):133-136

Kato T, Kamichika M (2006) Determination of a crop coefficient for evapotranspiration in a sparse sorghum field. Irrig Drain 55(2): 165-175

Körner C, Scheel JA, Bauer H (1979) Maximum leaf conductance in vascular plants. Photosynthetica 13(1):45-82

López-Urrea R, de Martín Santa Olalla F, Montoro A, López-Fuster P (2009a) Single and dual crop coefficients and water requirements for onion (Allium cepa L.) under semiarid conditions. Agric Water Manage 96(6):1031-1036

López-Urrea R, Montoro A, López-Fuster P, Fereres E (2009b) Evapotranspiration and responses to irrigation of broccoli. Agric Water Manage 96(7):1155-1161

López-Urrea R, Montoro A, González-Piqueras J, López-Fuster P, Fereres E (2009c) Water use of spring wheat to raise water productivity. Agric Water Manage. doi:10.1016/j.agwat.2009. 04.015

Mutziger AJ, Burt CM, Howes DJ, Allen RG (2005) Comparison of measured and FAO-56 modeled evaporation from bare soil. J Irrig Drain Eng 131(1):59-72

Paço TA, Ferreira MI, Conceição N (2006) Peach orchard evapotranspiration in a sandy soil: comparison between eddy covariance measurements and estimates by the FAO 56 approach. Agric Water Manage 85(3):305-313

Pastor M, Orgaz F (1994) Los programas de recorte de riego en olivar. Agricultura no 746:768-776 (in Spanish)

Pereira LS, Perrier A, Allen RG, Alves I (1999) Evapotranspiration: concepts and future trends. J Irrig Drain Eng ASCE 125(2):45-51

Pereira LS, Cai LG, Hann MJ (2003) Farm water and soil management for improved water use in the North China Plain. Irrig Drain 52(4):299-317

Popova Z, Eneva S, Pereira LS (2006) Model validation, crop coefficients and yield response factors for maize irrigation scheduling based on long-term experiments. Biosyst Eng 95(1):139-149

Raes D, Steduto P, Hsiao TC, Fereres E (2009) AquaCrop Reference Manual. Food and Agriculture Organization, Rome, 135 p. http://www.fao.org/nr/water/aquacrop.html

Ringersma J, Sikking AFS (2001) Determining transpiration coefficients of Sahelian vegetation barriers. Agrofor Syst 51:1-9

Ritchie JT (1974) Evaluating irrigation needs for southeastern U.S.A. In: Proceedings of irrigation and drainage special conference on American Society of Civil Engineers, pp 262-273

Rogers JS, Allen LH, Calvert DJ (1983) Evapotranspiration for humid regions: developing citrus grove, grass cover. Trans ASAE 26(6):1778-1783, 1792

Rolim J, Godinho P, Sequeira B, Rosa R, Paredes P, Pereira LS (2006) SIMDualKc, a software tool for water balance simulation based on dual crop coefficient. In: Zazueta F, Xin J, Ninomiya S, Schiefer G (eds) Computers in agriculture and natural resources (4th world congress, Orlando, FL), ASABE, St. Joseph, MI, pp 781-786

Snyder RL, Eching S (2005) Urban landscape evapotranspiration. In: The California state water plan, vol 4. Sacramento, CA, pp 691-693. http://www.waterplan.water.ca.gov/reference/index. cfm\#infrastructure

Snyder RL, Lanini BJ, Shaw DA, Pruitt WO (1989a) Using reference evapotranspiration (ETo) and crop coefficients to estimate crop evapotranspiration (ETc.) for agronomic crops, grasses, and vegetable crops. Cooperative Extension, University of California, Berkeley, Leaflet No. 21427, 12 p 
Snyder RL, Lanini BJ, Shaw DA, Pruitt WO (1989b) Using reference evapotranspiration (ETo) and crop coefficients to estimate crop evapotranspiration (ETc.) for trees and vines. Cooperative Extension, University of California, Berkeley, Leaflet No. 21428, $8 \mathrm{p}$

Spohrer K, Jantschke C, Herrmann L, Engelhardt M, Pinmanee S, Stahr K (2006) Lychee tree parameters for water balance modeling. Plant Soil 284(1-2):59-72

Testi L, Villalobos FJ, Orgaza F (2004) Evapotranspiration of a young irrigated olive orchard in southern Spain. Agric For Meteor 121(1-2):1-18

Tolk JA, Howell TA (2001) Measured and simulated evapotranspiration of grain sorghum with full and limited irrigation in three High Plains soils. Trans ASAE 44(6):1553-1558
Villalobos FJ, Orgaz F, Testi L, Fereres E (2000) Measurement and modeling of evapotranspiration of olive orchards. Eur J Agron 13:155-163

Wright JL (1982) New evapotranspiration crop coefficients. J Irrig Drain Div ASCE 108:57-74

Yang D, Zhang T, Zhang K, Greenwood DJ, Hammond JP, White PJ (2009) An easily implemented agro-hydrological procedure with dynamic root simulation for water transfer in the crop-soil system: validation and application. J Hydrol 370(1-4):177-190

Zhao C, Nan Z (2007) Estimating water needs of maize (Zea mays L.) using the dual crop coefficient method in the arid region of northwestern China. Afr J Agric Res 2(7):325-333 